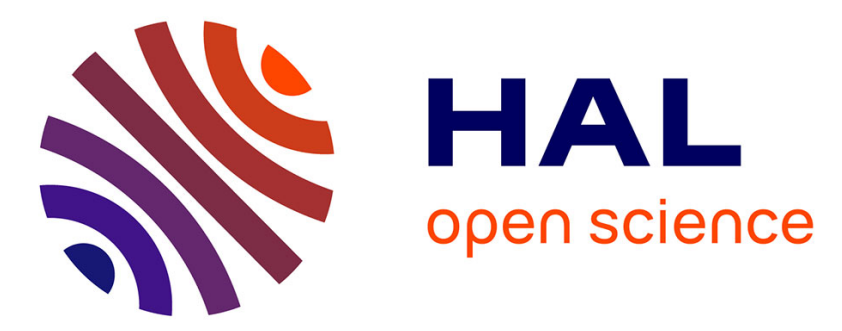

\title{
Fluorescent Anthracene-based Anion Receptors
}

Philip Alan Gale

\section{- To cite this version:}

Philip Alan Gale. Fluorescent Anthracene-based Anion Receptors. Supramolecular Chemistry, 2009, 20 (04), pp.349-355. 10.1080/10610270701258121 . hal-00513505

\section{HAL Id: hal-00513505 \\ https://hal.science/hal-00513505}

Submitted on 1 Sep 2010

HAL is a multi-disciplinary open access archive for the deposit and dissemination of scientific research documents, whether they are published or not. The documents may come from teaching and research institutions in France or abroad, or from public or private research centers.
L'archive ouverte pluridisciplinaire HAL, est destinée au dépôt et à la diffusion de documents scientifiques de niveau recherche, publiés ou non, émanant des établissements d'enseignement et de recherche français ou étrangers, des laboratoires publics ou privés. 


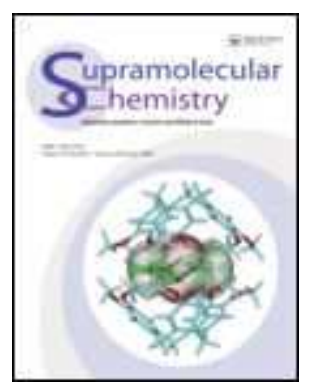

\section{Fluorescent Anthracene-based Anion Receptors}

\begin{tabular}{|r|l|}
\hline Journal: & Supramolecular Chemistry \\
\hline Manuscript ID: & GSCH-2006-0128.R1 \\
\hline Manuscript Type: & Full Paper \\
\hline Date Submitted by the \\
Author: & 31 -Jan-2007 \\
\hline Keywords: & anion receptors, urea, fluorescence, crystallography \\
\hline Complete List of Authors: & Gale, Philip; University of Southampton, School of Chemistry \\
\hline & \\
\hline $\begin{array}{l}\text { Note: The following files were submitted by the author for peer review, but cannot be converted } \\
\text { to PDF. You must view these files (e.g. movies) online. }\end{array}$ \\
\hline \begin{tabular}{l} 
1-6.cdx \\
\hline
\end{tabular}
\end{tabular}

\section{scholarONE \\ Manuscript Central}




\section{Fluorescent anthracene-based anion receptors}

Simon J. Brooks, ${ }^{\mathrm{a}}$ Claudia Caltagirone, ${ }^{\mathrm{a}}$ Aimee J. Cossins, ${ }^{\mathrm{b}}$ Philip A. Gale*,a and Mark E. Light ${ }^{\mathrm{a}}$

Supplementary Information. 


\section{${ }^{1}$ H NMR TITRATION CURVES.}

$N^{1}, N^{2}$-dibutylanthracene-1,2-dicarboxamide (1) in $\mathrm{CD}_{2} \mathrm{Cl}_{2}-d_{2}$.

Benzoate.

$\mathrm{K}_{\mathrm{a}}=709$

Error $=1.6 \%$
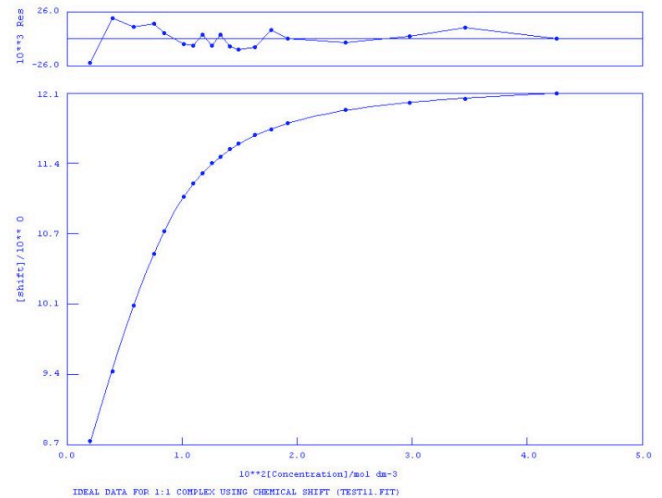

Chloride.

$\mathrm{K}_{\mathrm{a}}=238$

Error $=1.4 \%$
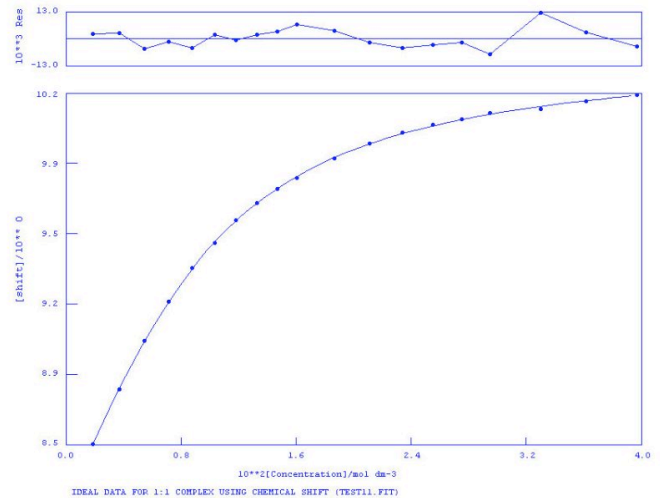

Hydrogen Sulfate.

$\mathrm{K}_{\mathrm{a}}=14$

Error $=11.3 \%$
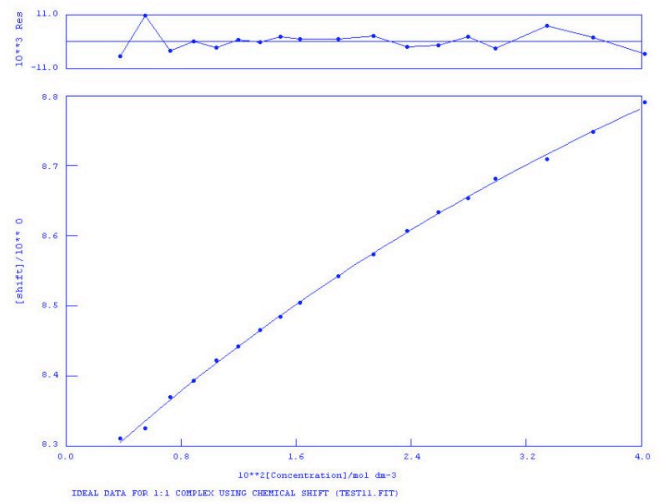

Bromide.

$\mathrm{K}_{\mathrm{a}}=67$

Error $=1.4 \%$
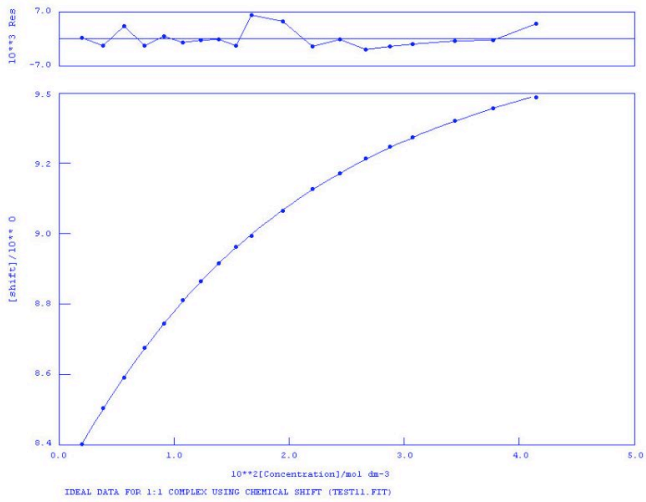

Dihydrogen Phosphate.

$\mathrm{K}_{\mathrm{a}}=128$

Error $=2.3 \%$

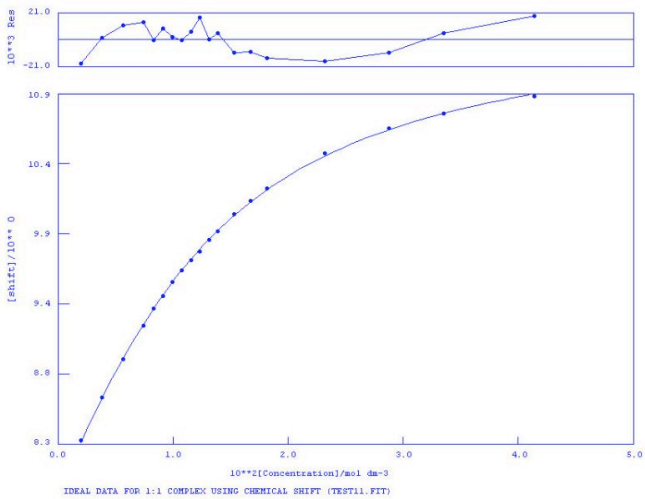




\section{$N^{1}, N^{3}$-dibutylanthracene-1,3-dicarboxamide (3) in $\mathrm{CD}_{2} \mathrm{Cl}_{2}-d_{2}$.}

Benzoate.

$\mathrm{K}_{\mathrm{a}}=173$

Error $=2.2 \%$
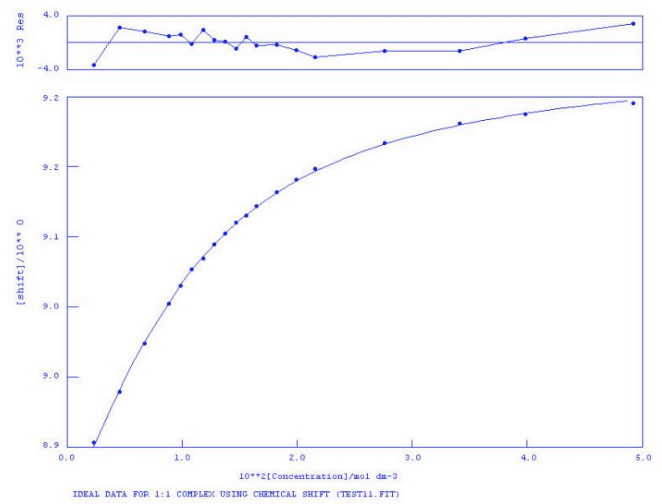

Chloride.

$\mathrm{K}_{\mathrm{a}}=257$

Error $=4.7 \%$
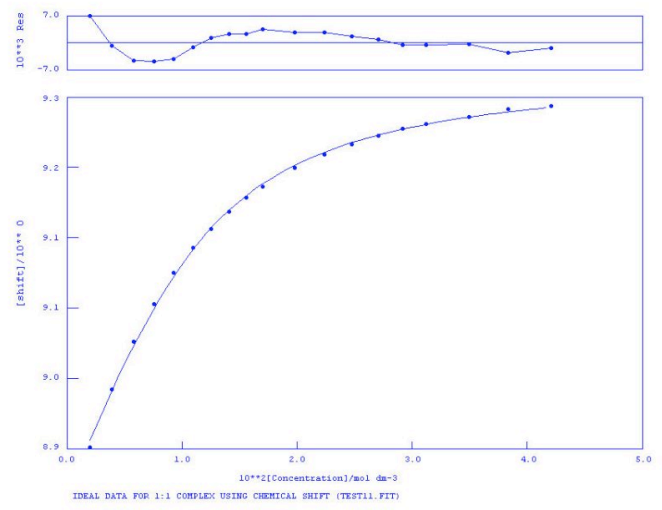

Hydrogen Sulfate.

$\mathrm{K}_{\mathrm{a}}=16$

Error $=10.0 \%$
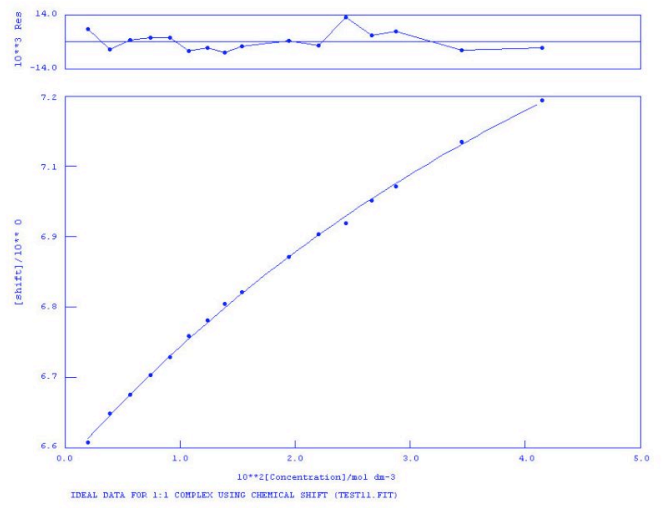

Bromide.

$\mathrm{K}_{\mathrm{a}}=92$

Error $=2.0 \%$

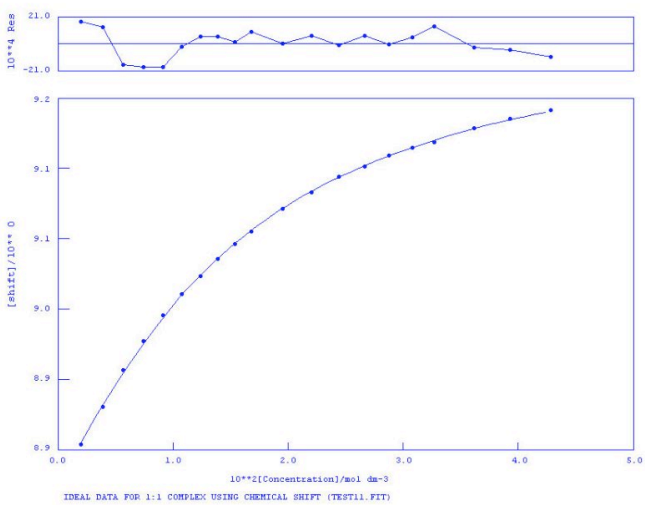

Dihydrogen Phosphate.

$\mathrm{Ka}=52$

Error $=2.9 \%$

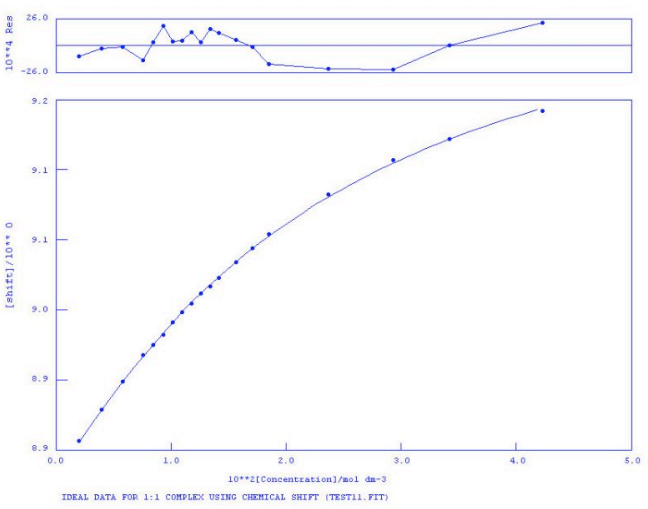


$N^{1}, N^{2}$-dibutylanthracene-1,2-dicarboxamide (1) in DMSO- $d_{6} / 0.5 \%$ water.

Acetate.

$\mathrm{K}_{\mathrm{a}}=85$

Error $=0.9 \%$

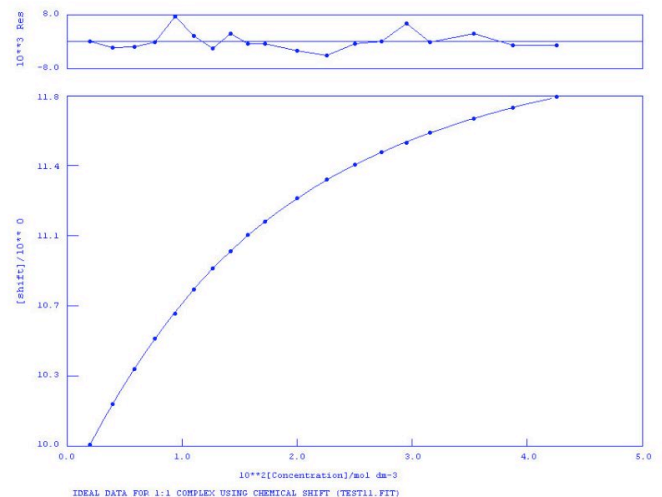

Chloride.

$\mathrm{K}_{\mathrm{a}}=<10$

Error $=4.5 \%$
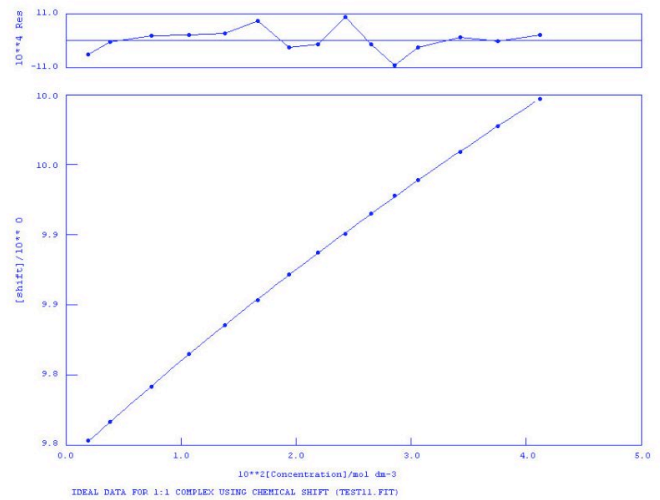

Benzoate.

$\mathrm{K}_{\mathrm{a}}=44$

Error $=2.1 \%$

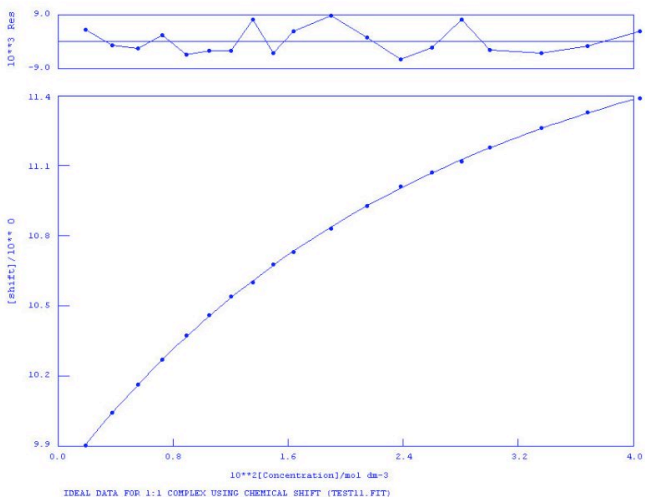

Dihydrogen Phosphate.

$\mathrm{K}_{\mathrm{a}}=64$

Error $=5.4 \%$

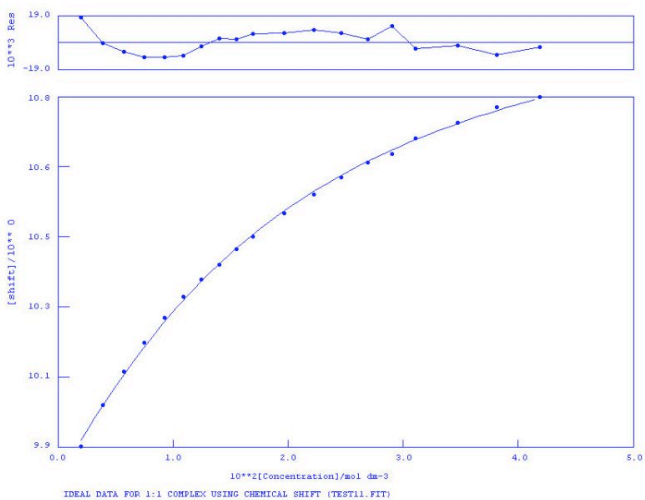


$N^{1}, N^{2}$-diphenylanthracene-1,2-dicarboxamide (2) in DMSO- $d_{6} / 0.5 \% \mathrm{H}_{2} \mathrm{O}$.

Acetate.

$\mathrm{K}_{\mathrm{a}}=28$

Error $=6.1 \%$

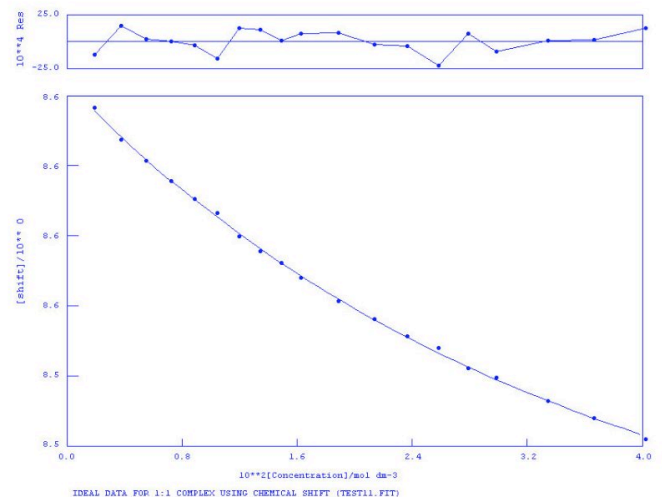

Chloride.

$\mathrm{K}_{\mathrm{a}}=<10$

Error $=10.7 \%$

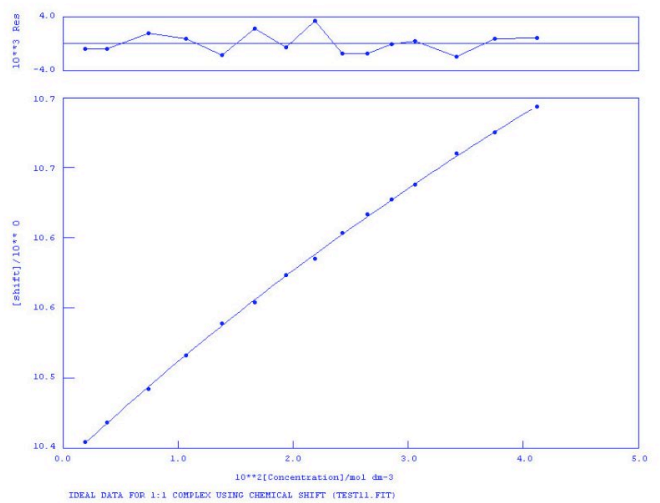

Benzoate.

$\mathrm{K}_{\mathrm{a}}=34$

Error $=3.9 \%$

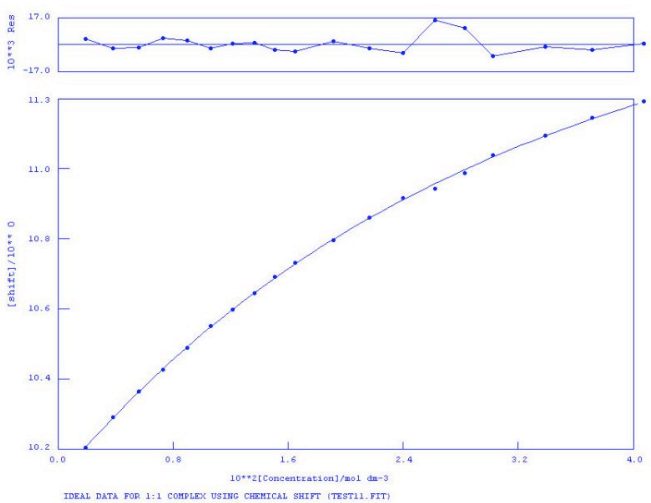

Dihydrogen Phosphate.

$\mathrm{K}_{\mathrm{a}}=63$

Error $=4.1 \%$

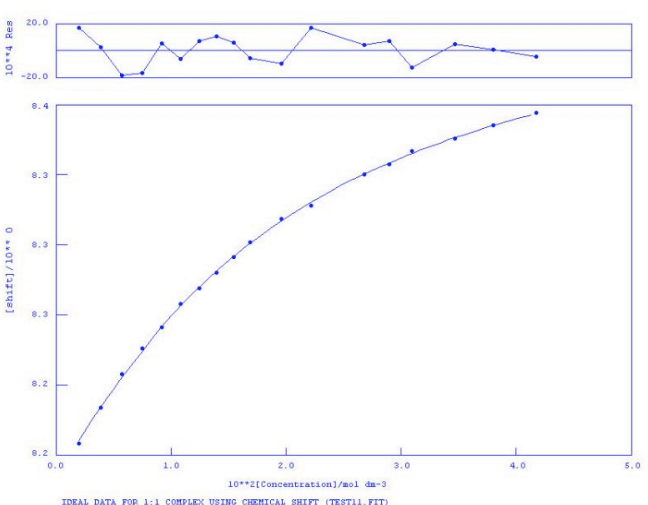


$N^{1}, N^{3}$-dibutylanthracene-1,3-dicarboxamide (3) in DMSO- $d_{6} / 0.5 \%$ water.

Acetate.

$\mathrm{K}_{\mathrm{a}}=13$

Error $=5.8 \%$

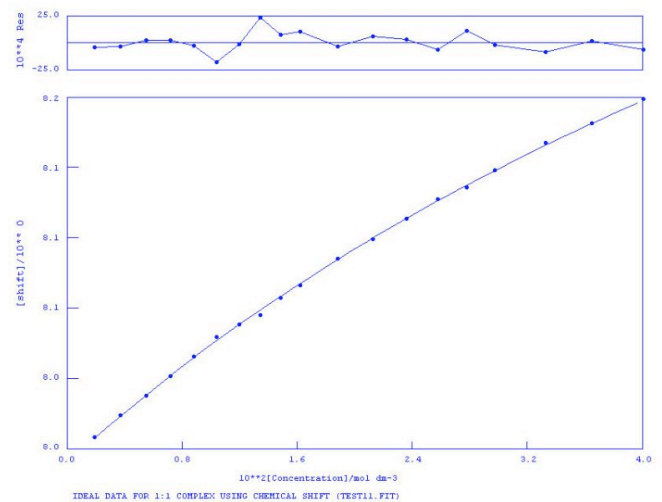

Chloride.

$\mathrm{Ka}=<10$

Error $=33.0 \%$

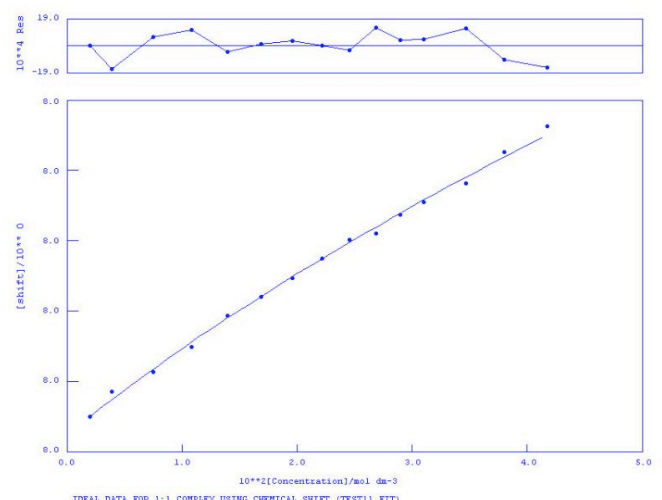

Benzoate.

$\mathrm{K}_{\mathrm{a}}=<10$

Error $=9.6 \%$

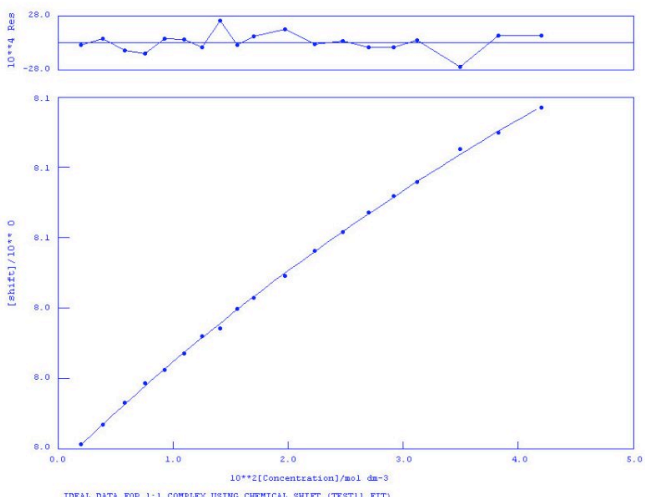

Dihydrogen Phosphate.

$\mathrm{Ka}=19$

Error $=10.9 \%$

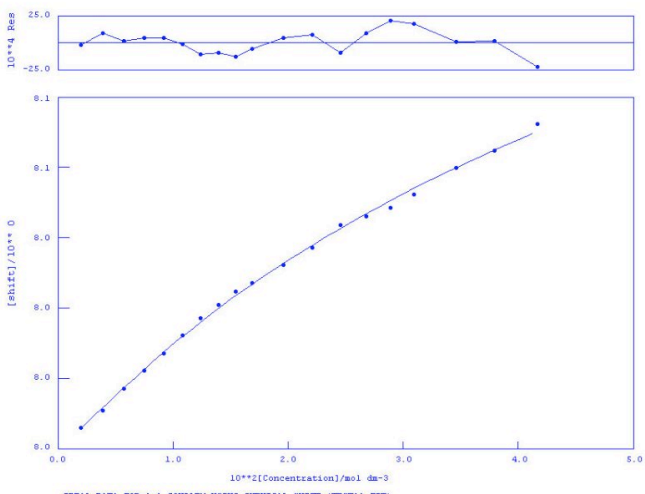

40

41

42

43

44

45

46

47

48

49

50

51

52

53

54

55

56

57

58

59

60 


\section{$N^{1}, N^{3}$-diphenylanthracene-1,3-dicarboxamide (4) in DMSO- $d_{6} / 0.5 \%$ water.}

Acetate.

$\mathrm{K}_{\mathrm{a}}=37$

Error $=3.3 \%$

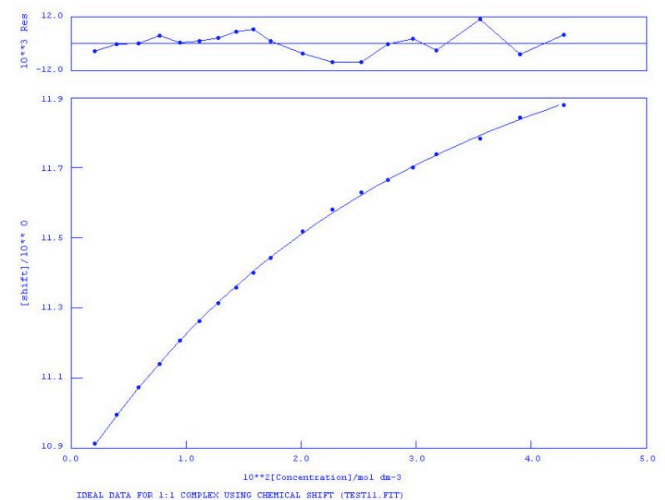

Chloride.

$\mathrm{K}_{\mathrm{a}}=<10$

Error $=7.1 \%$

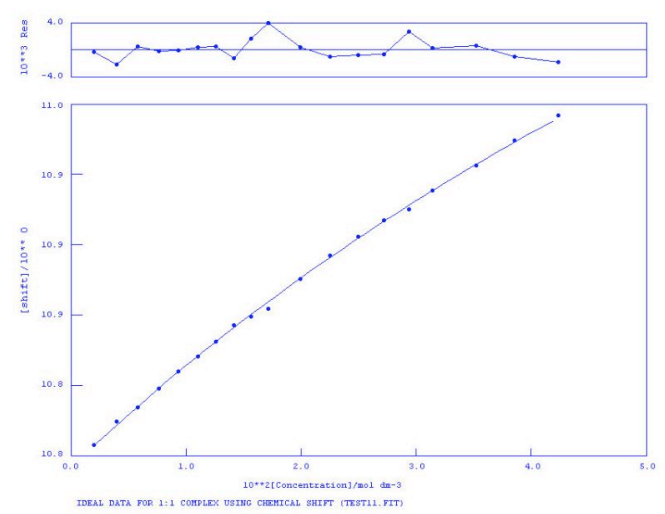

Benzoate.

$\mathrm{K}_{\mathrm{a}}=21$

Error $=2.4 \%$

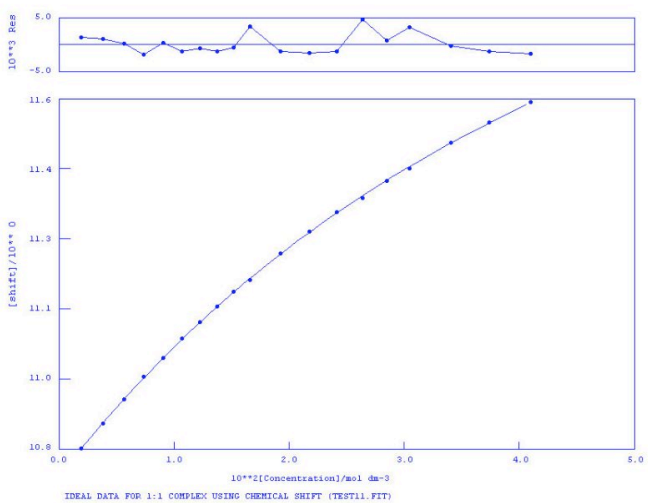

Dihydrogen Phosphate.

$\mathrm{K}_{\mathrm{a}}=122$

Error $=6.6 \%$

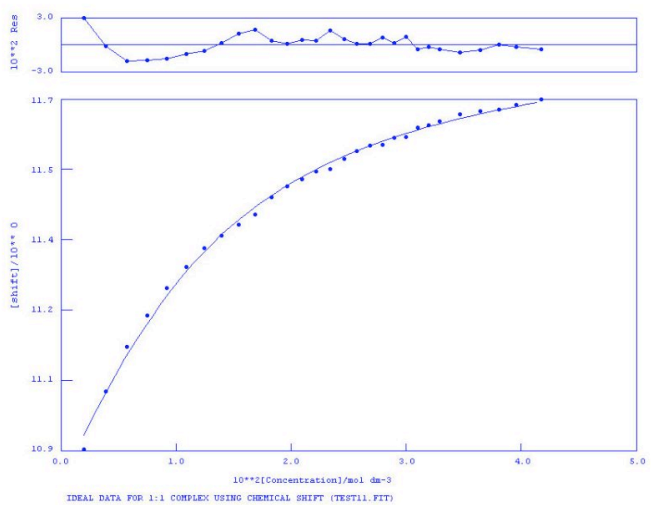


1,2-Anthracene bis-butylurea (5) in DMSO- $d_{6} / 0.5 \%$ water.

Acetate.

$\mathrm{K}_{\mathrm{a}}=277$

Error $=1.0 \%$

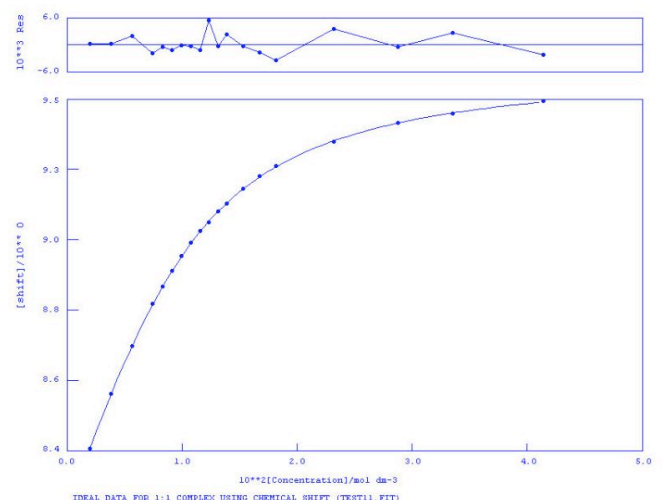

Chloride.

$\mathrm{K}_{\mathrm{a}}=10$

Error $=13.2 \%$

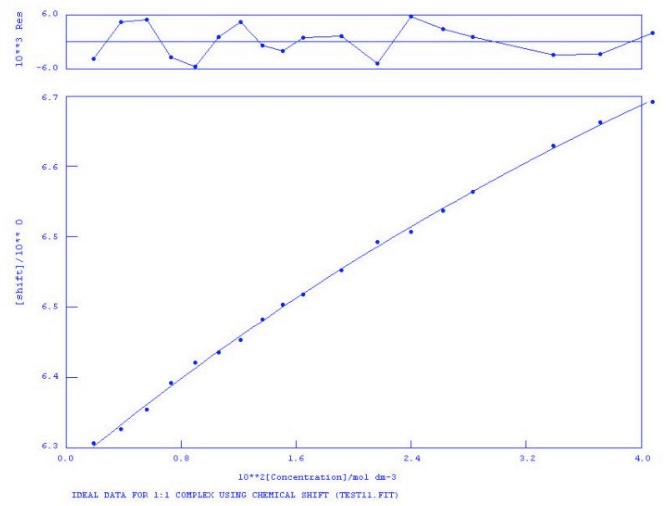

Benzoate.

$\mathrm{K}_{\mathrm{a}}=107$

Error $=1.2 \%$

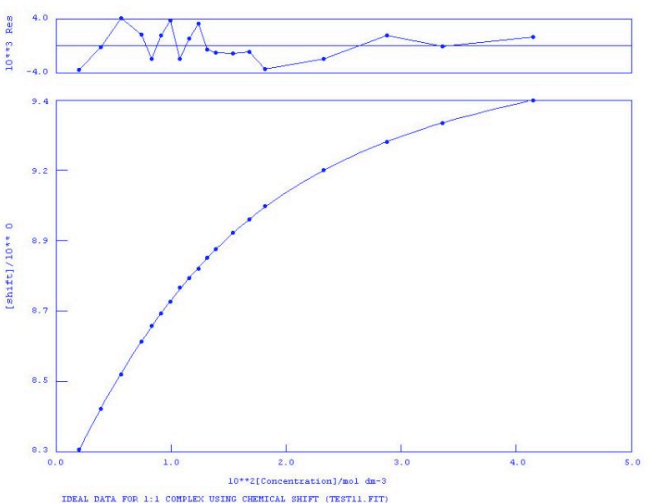

Dihydrogen Phosphate.

$\mathrm{K}_{\mathrm{a}}=370$

Error $=2.1 \%$

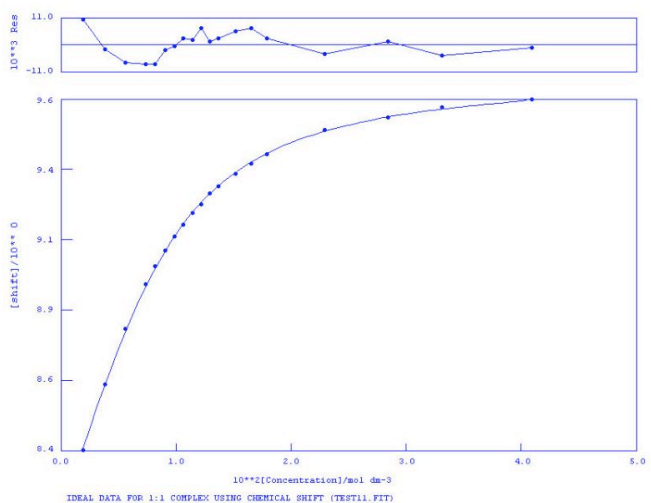


1,2-Anthracene bis-phenylurea (6) in DMSO- $d_{6} / 0.5 \%$ water.

Acetate.

$\mathrm{K}_{\mathrm{a}}=2539$

Error $=1.4 \%$

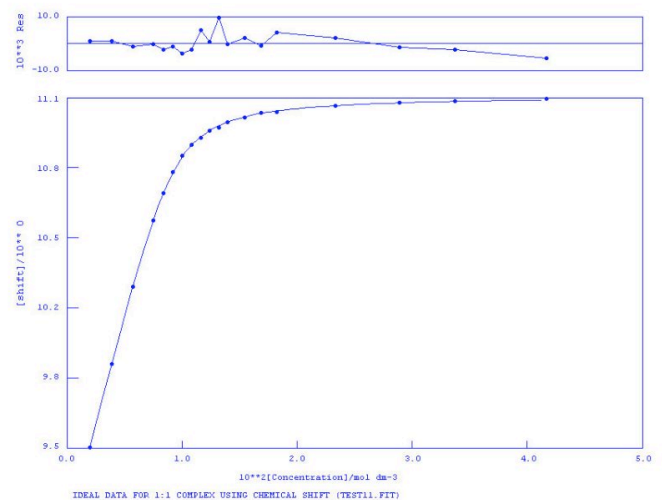

Bromide.

$\mathrm{K}_{\mathrm{a}}=<10$

Error $=29.9 \%$
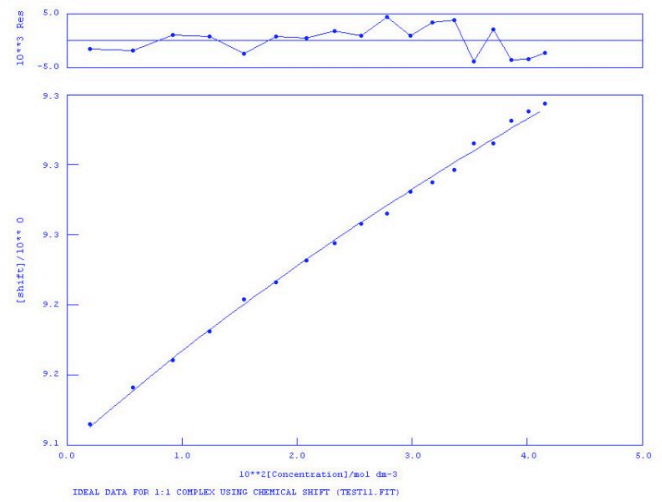

Dihydrogen Phosphate.

$\mathrm{K}_{\mathrm{a}}=1166$

Error $=6.2 \%$

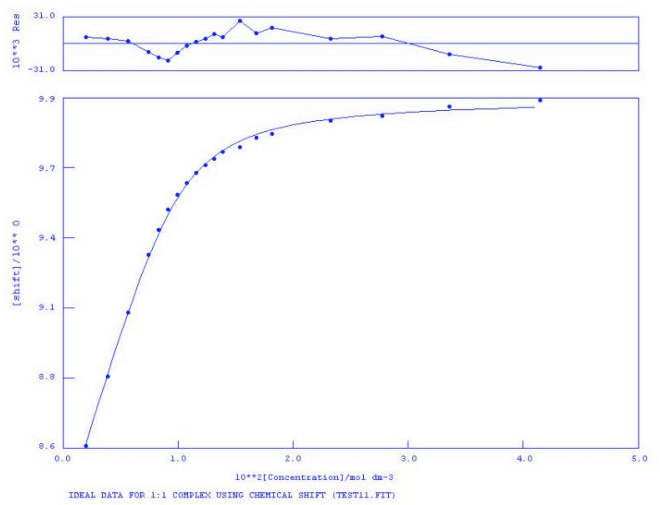

Benzoate.

$\mathrm{K}_{\mathrm{a}}=586$

Error $=2.9 \%$

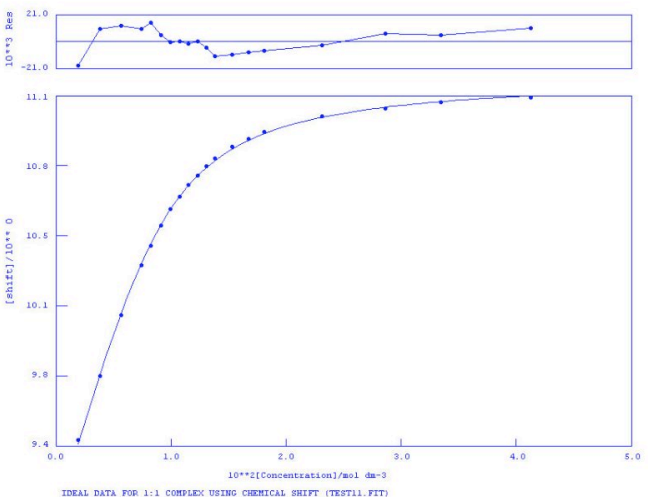

Chloride.

$\mathrm{K}_{\mathrm{a}}=27$

Error $=2.4 \%$

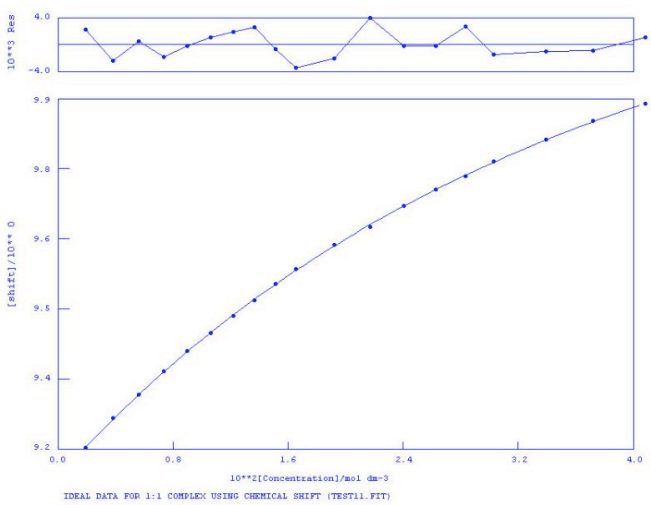

41

45

46

47

48

49

50

51

52

53

54

55

56

57

58

59

60 


\section{FLUORESCENCE INTENSITY/MOLAR RATIO PLOTS FOR 5}

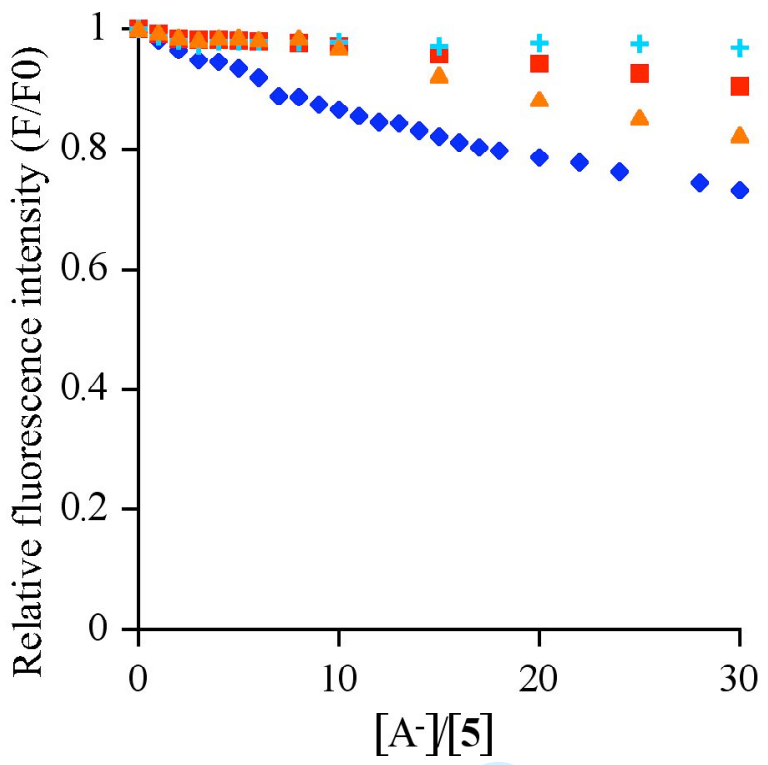

Fig. S1 Fluorescence intensity/molar ratio plots for $5\left[1 \times 10^{-6} \mathrm{M}\right.$, MeCN/DMSO $\left.(96.5 / 3.5 \mathrm{v} / \mathrm{v})\right]$ in the presence of increasing amounts of $\mathrm{AcO}^{-}(\downarrow), \mathrm{H}_{2} \mathrm{PO}_{4}{ }^{2-}(\triangle), \mathrm{BzO}^{-}(\varpi)$ and $\mathrm{Cl}^{-}(+)$. 


\section{ADDITIONAL CRYSTAL IMAGES}
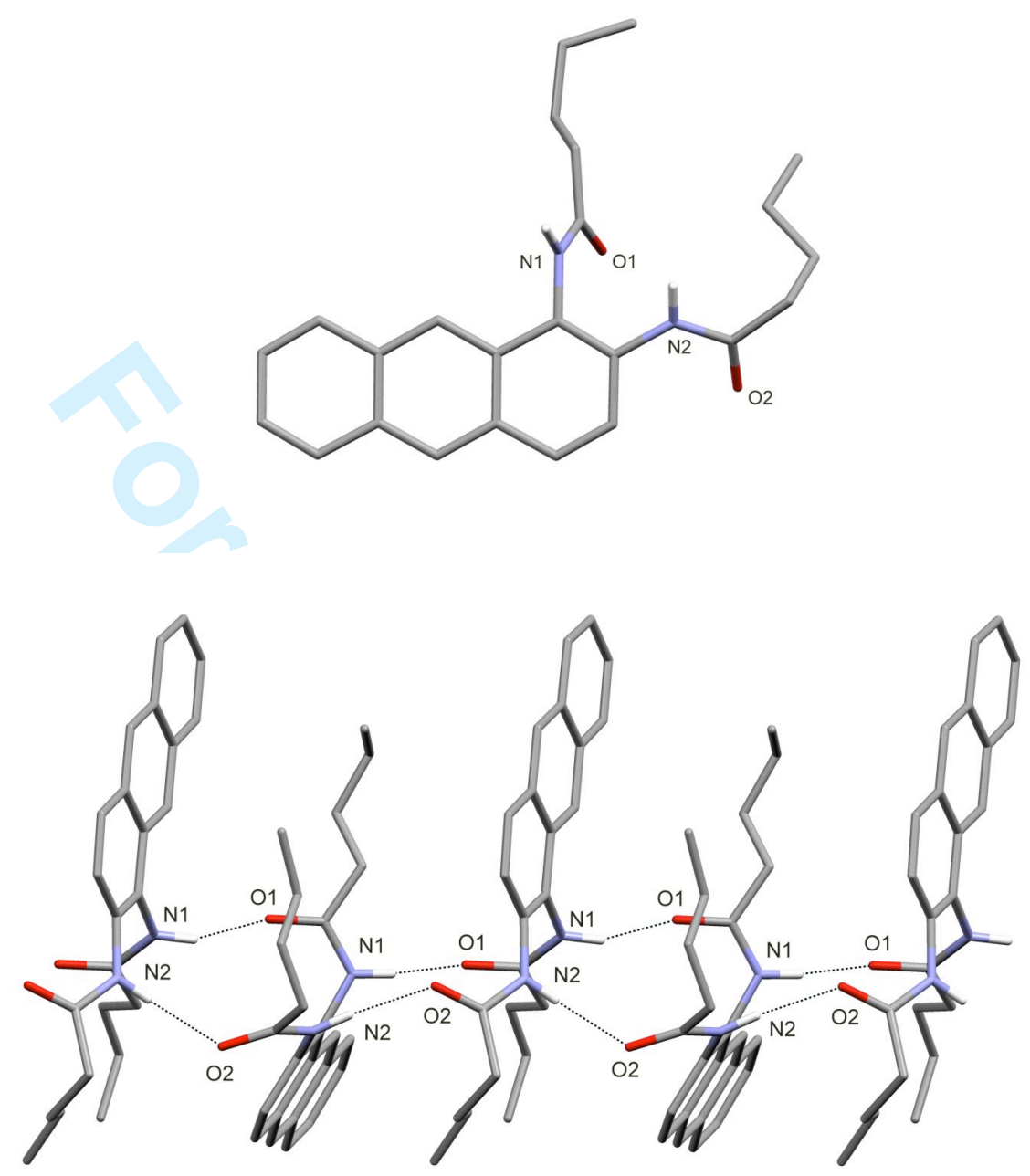

Fig. S2 The solid state structure of $\mathbf{1}$ obtained from acetonitrile solution, reveals extensive hydrogen bonding interactions in the solid state. Non-acidic protons omitted for clarity. 

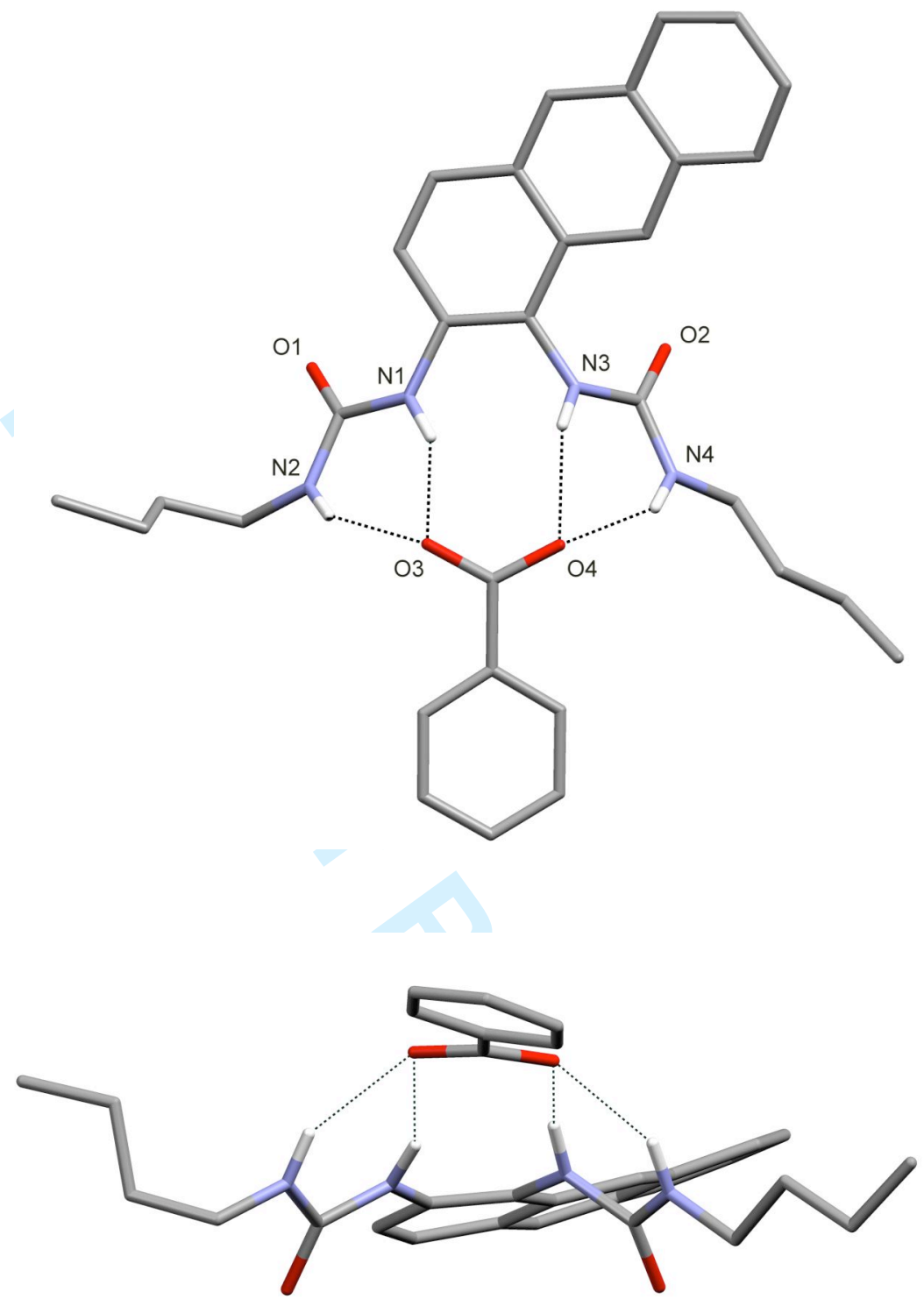

Fig. S3 Benzoate complex of 5 reveals that the anion is bound simultaneously by all four NH donor groups. 


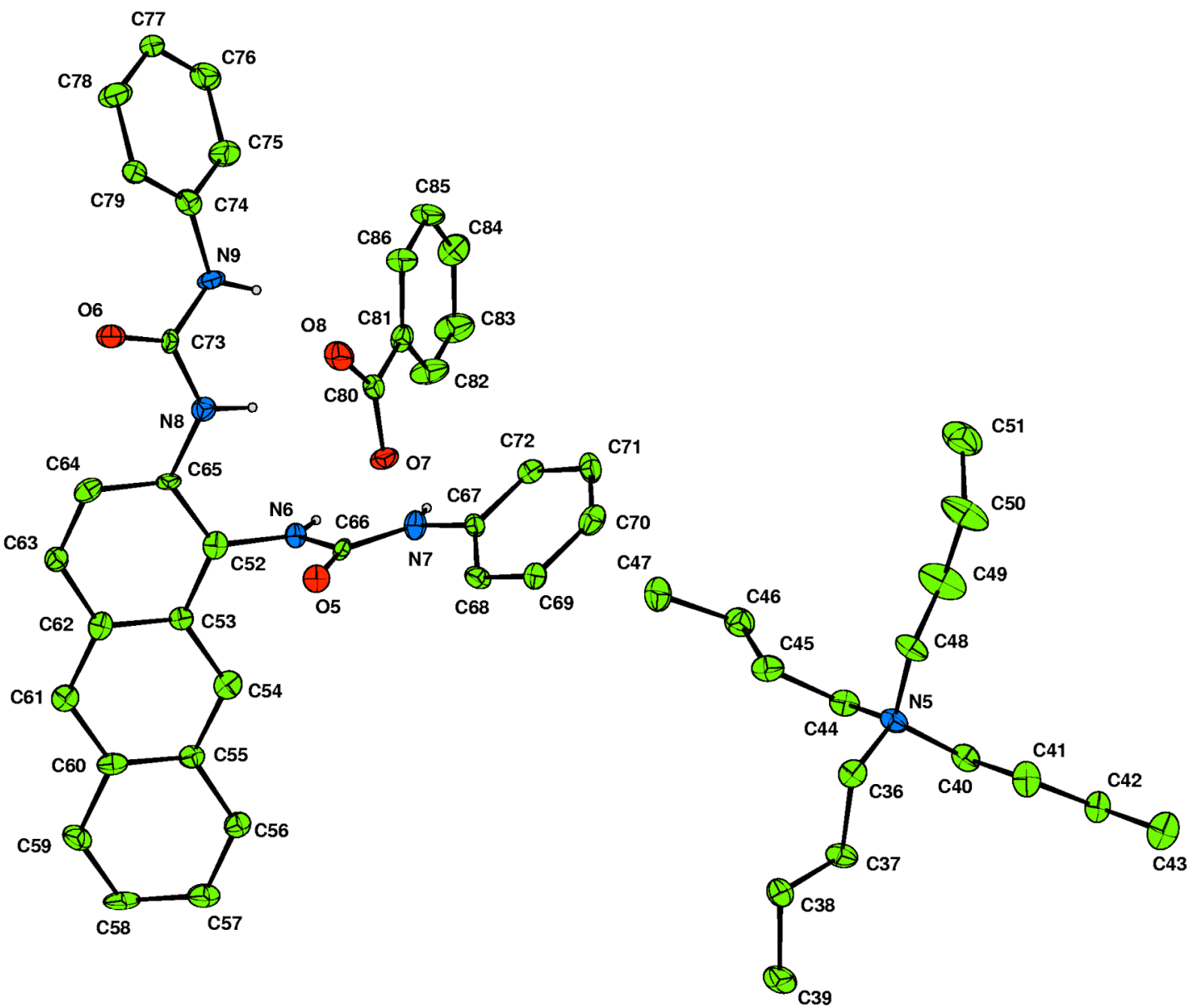

Figure S4 The Tetrabutylammonium benzoate complex of compound 6. Thermal ellipsoids drawn at the $35 \%$ probability level. Only half the contents of the asymmetric unit are shown 


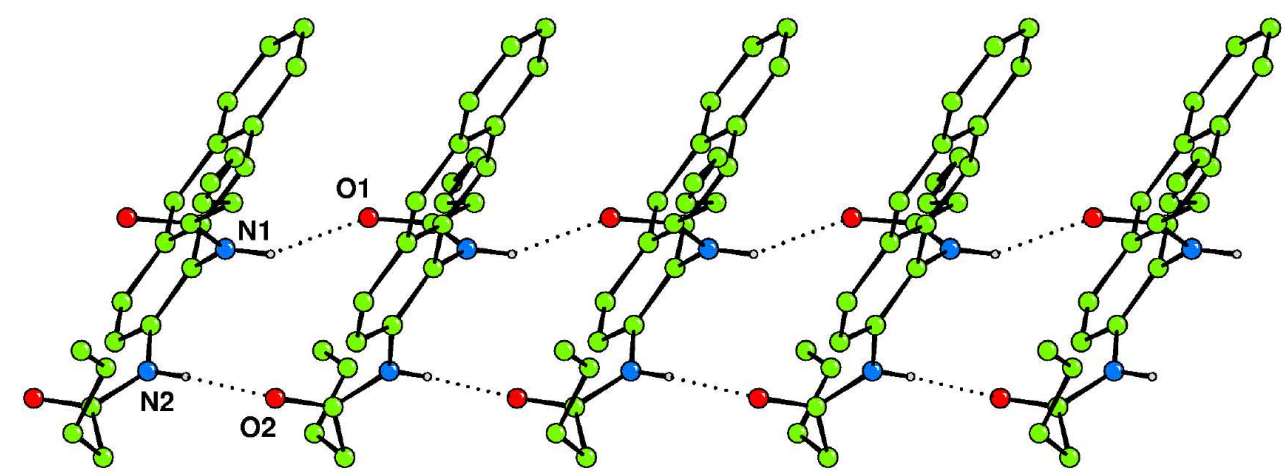

Figure 1. Receptor 1 forms hydrogen-bonded chains in the solid state. Non-acidic hydrogen atoms have been omitted for clarity.

$149 \times 54 \mathrm{~mm}(300 \times 300 \mathrm{DPI})$ 


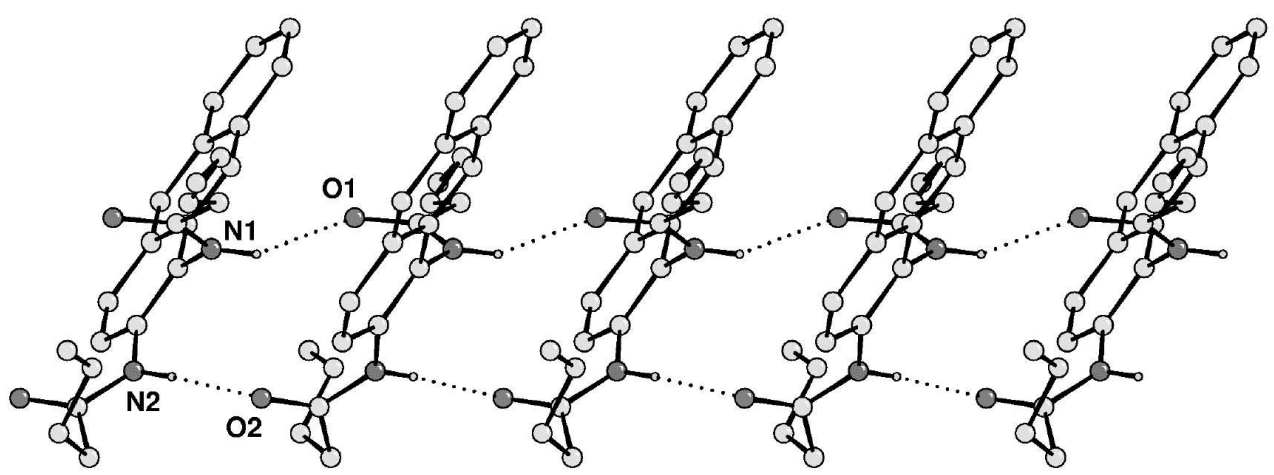

Figure 1. Receptor 1 forms hydrogen-bonded chains in the solid state. Non-acidic hydrogen atoms have been omitted for clarity. $149 \times 54 \mathrm{~mm}(300 \times 300$ DPI $)$ 


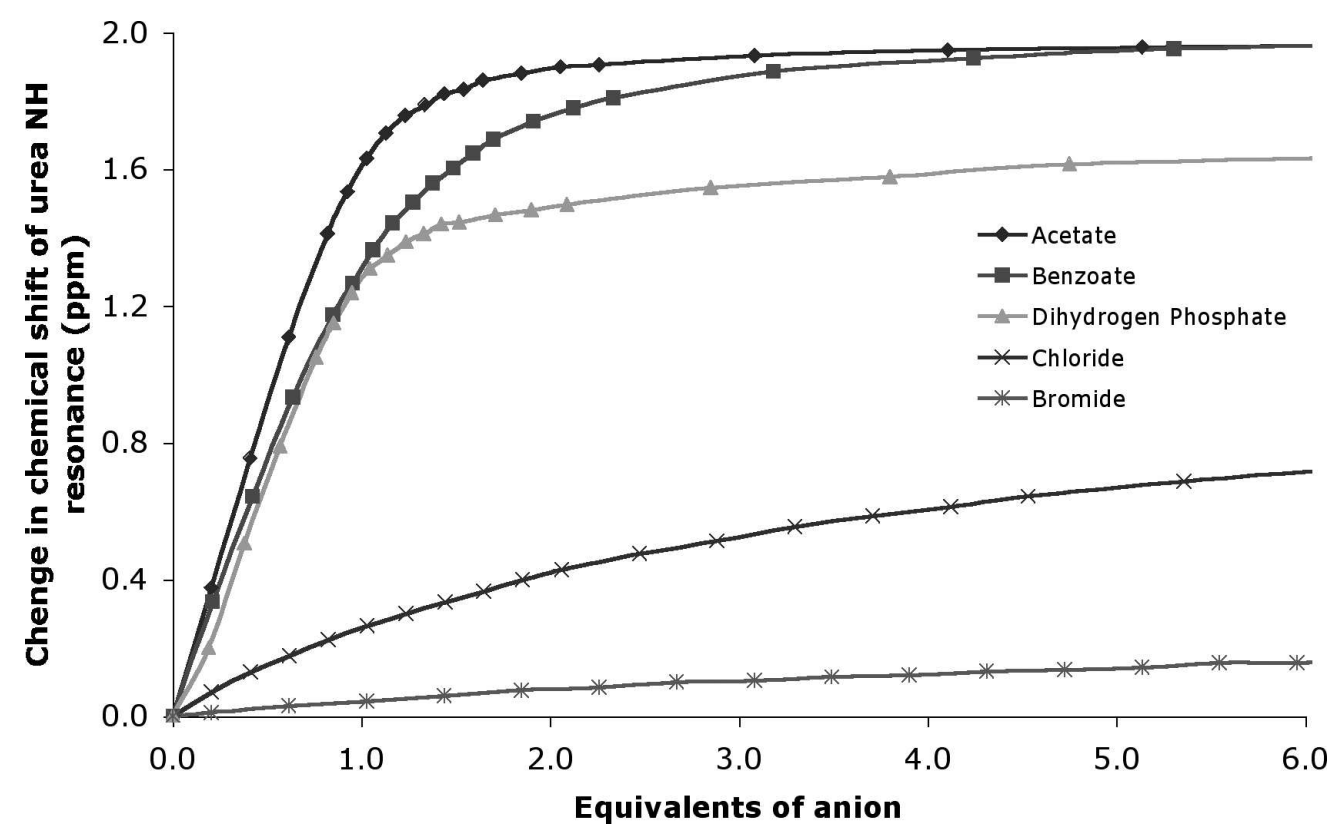

Figure 2. Shifts of the central urea NH groups of compound 6 upon the addition of tetrabutylammonium salts in DMSO-d6/0.5\% water. $143 \times 88 \mathrm{~mm}(300 \times 300$ DPI $)$ 


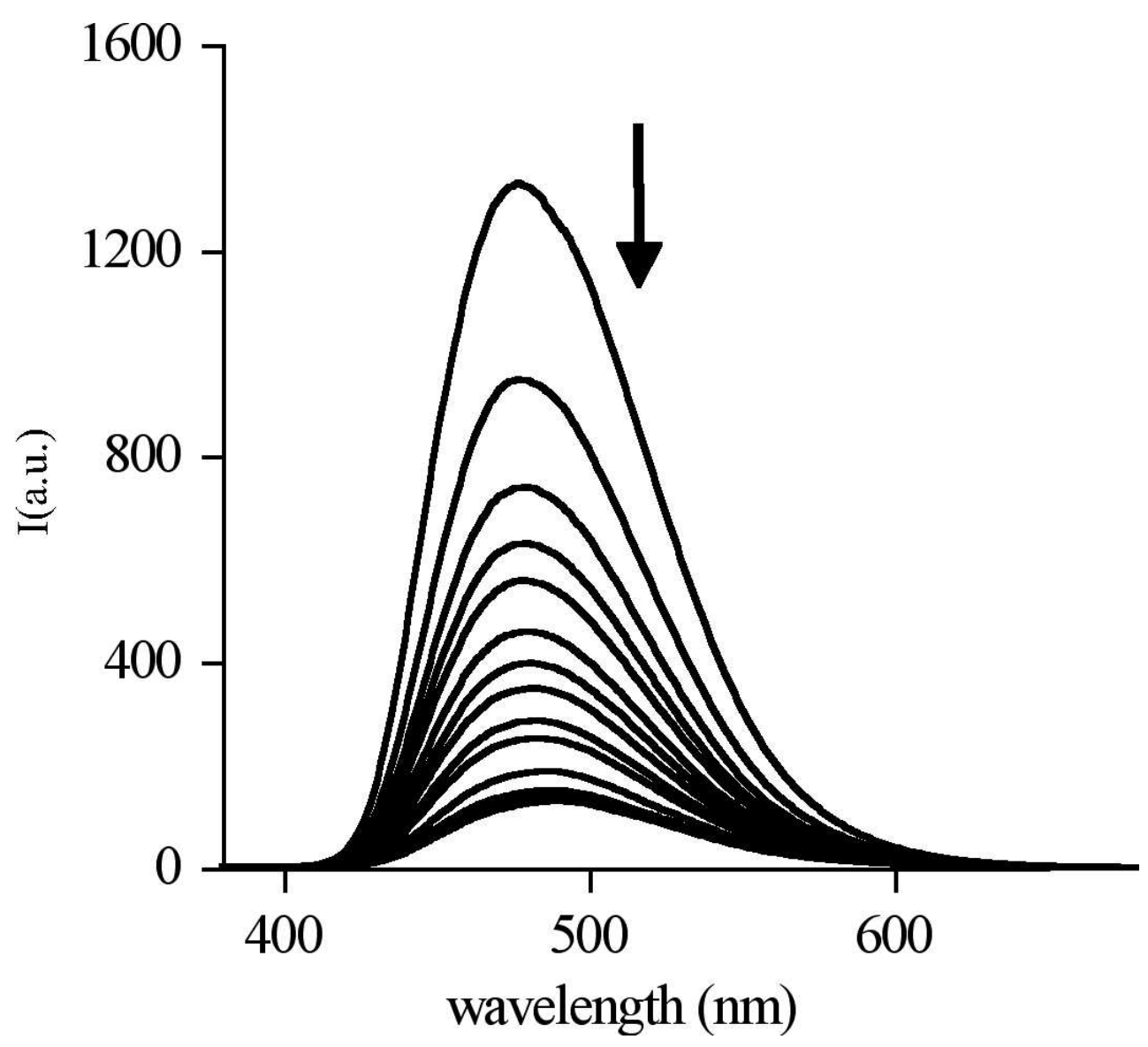

Figure 3. Fluorescence quenching of 6 in DMSO upon the addition of tetrabutylammonium acetate $92 \times 81 \mathrm{~mm}(300 \times 300 \mathrm{DPI})$ 


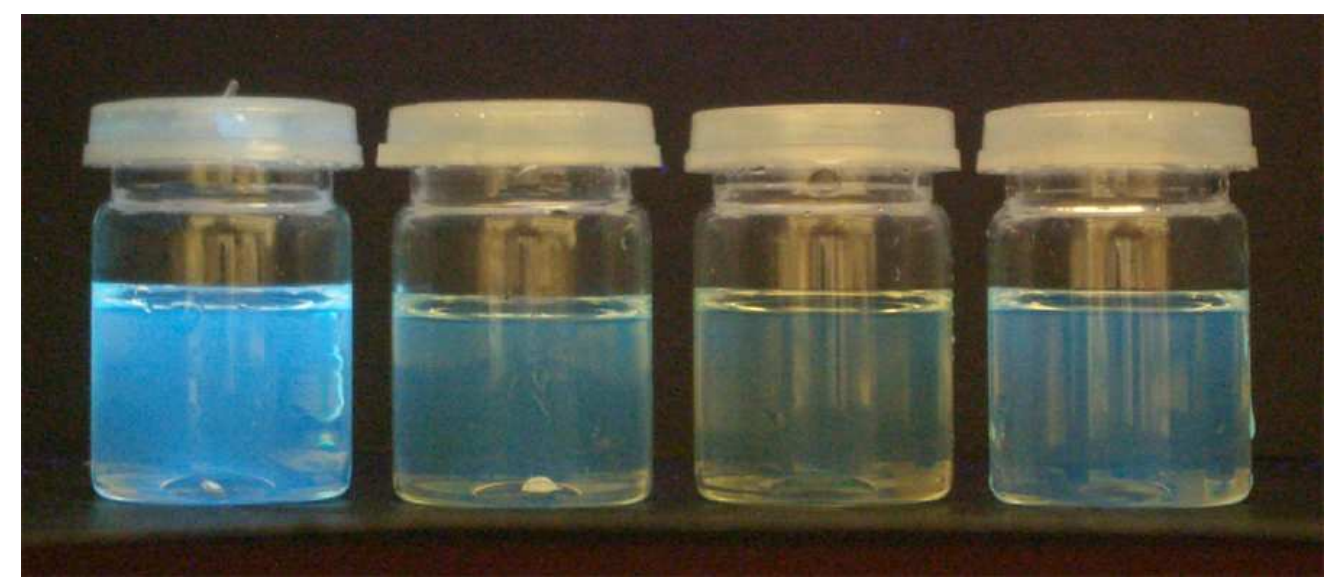

$76 \times 32 \mathrm{~mm}(300 \times 300 \mathrm{DPI})$ 
1

2

3

4

5

6

7

8

9

10

11

12

13

14

15

16

17

18

19

20

21

22

23

24

25

26

27

28

29

30

31

32

33

34

35

36

37

38

39

40

41

42

43

44

45

46

47

48

49

50

51

52

53

54

55

56

57

58

59

60

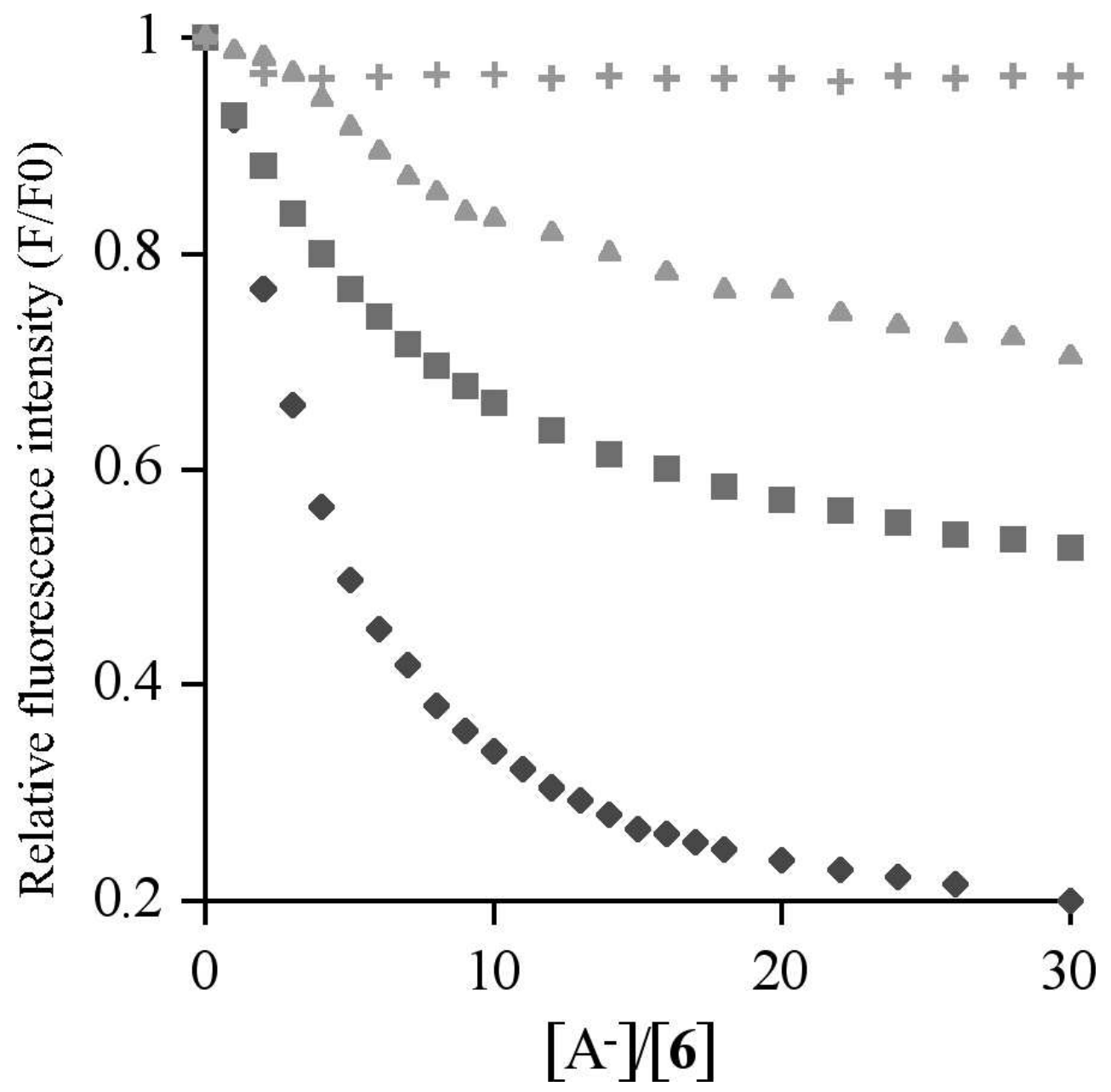

Figure 5. Fluorescence intensity/molar ratio plots for $6[1 \times 10$ ? $6 \mathrm{M}$, MeCN/DMSO $(96.5 / 3.5 \mathrm{v} / \mathrm{v})]$ in the presence of increasing amounts of $\mathrm{AcO}$ ? (?), $\mathrm{H} 2 \mathrm{PO} 4$ ? (?), $\mathrm{BzO}$ ? (?) and $\mathrm{Cl}$ ? (+). $78 \times 75 \mathrm{~mm}(300 \times 300 \mathrm{DPI})$ 


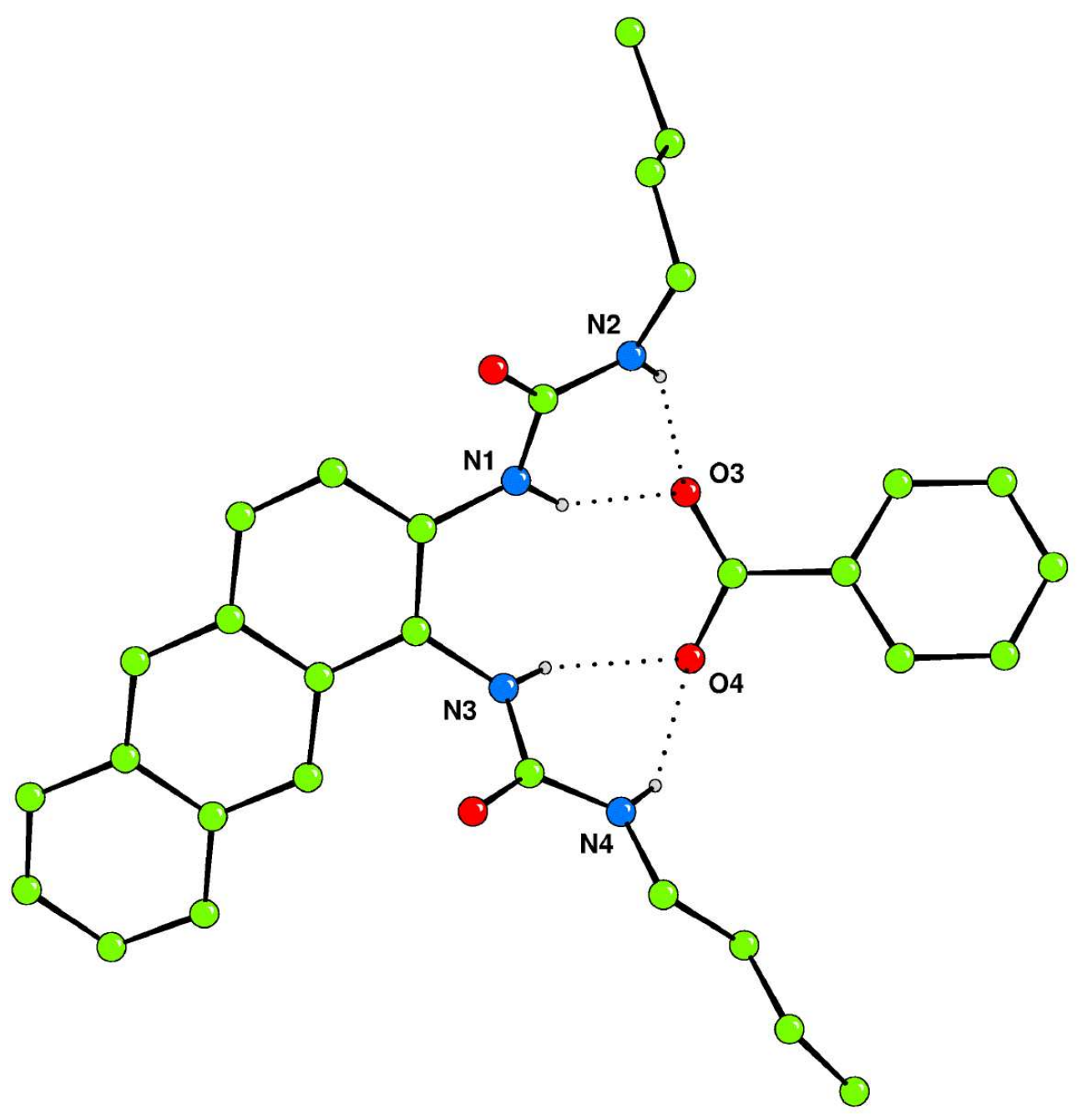

Figure 6 The benzoate complex of 5 showing the formation of four hydrogen bonds between the receptor and the carboxylate anion in the solid state. Tetrabutylammonium counter cations and non-acidic hydrogen atoms omitted for clarity. $100 \times 103 \mathrm{~mm}(300 \times 300 \mathrm{DPI})$ 


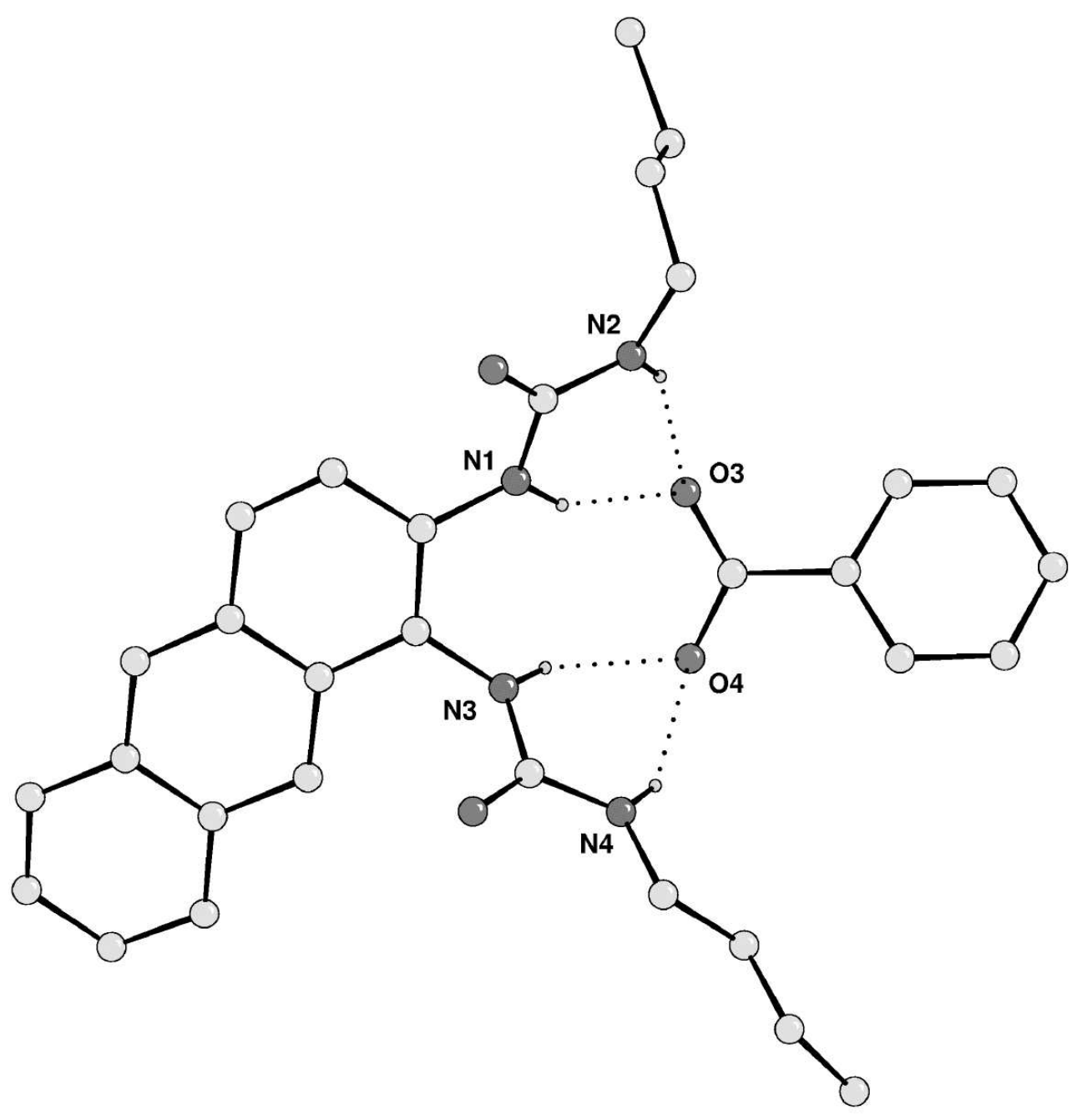

Figure 6 The benzoate complex of 5 showing the formation of four hydrogen bonds between the receptor and the carboxylate anion in the solid state. Tetrabutylammonium counter cations and non-acidic hydrogen atoms omitted for clarity. $100 \times 103 \mathrm{~mm}(300 \times 300 \mathrm{DPI})$ 


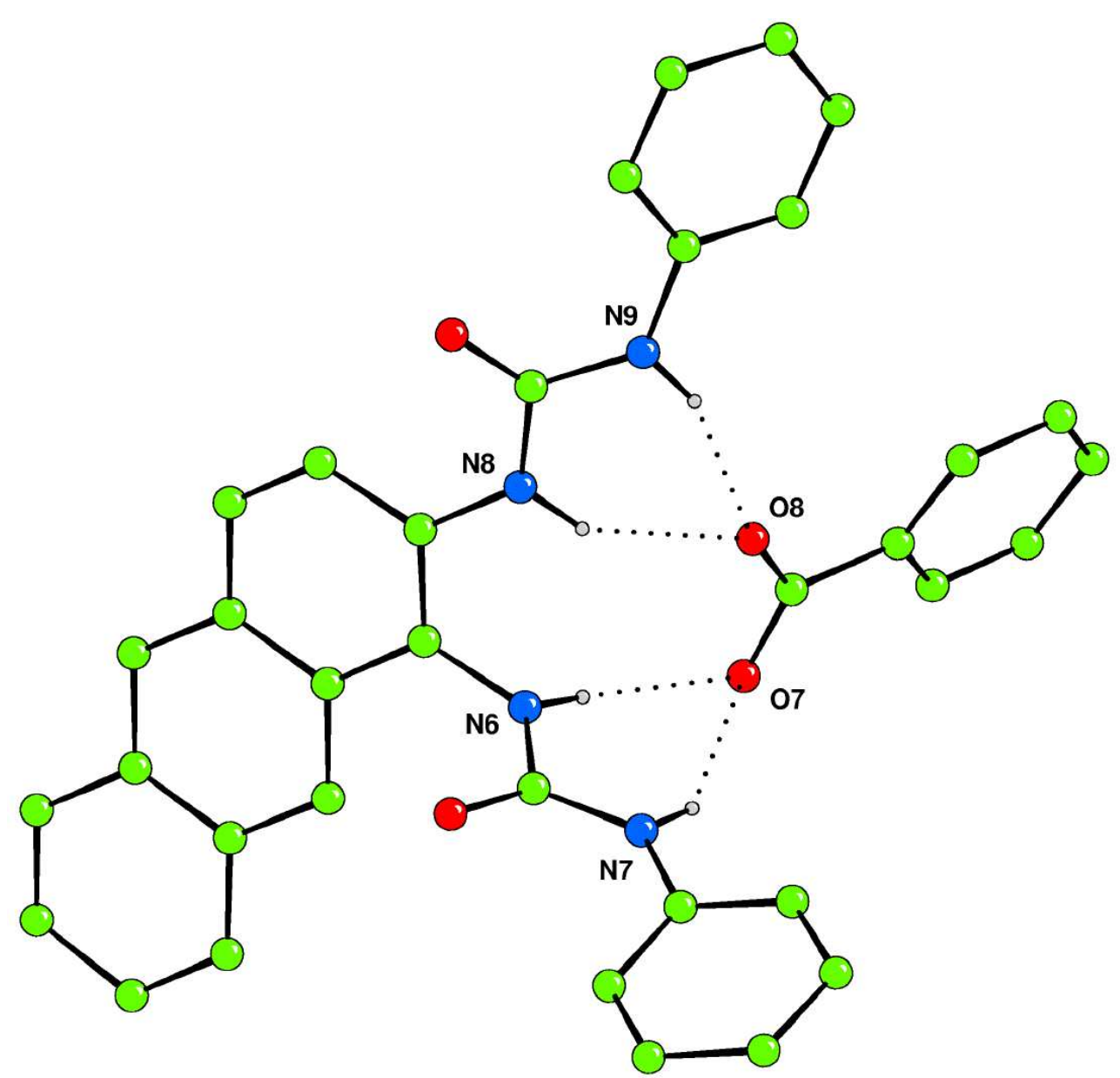

Figure 7 The benzoate complex of 6 showing the formation of four hydrogen bonds between the receptor and the carboxylate anion in the solid state. Tetrabutylammonium counter cations and non-acidic hydrogen atoms omitted for clarity $94 \times 89 \mathrm{~mm}(300 \times 300 \mathrm{DPI})$ 


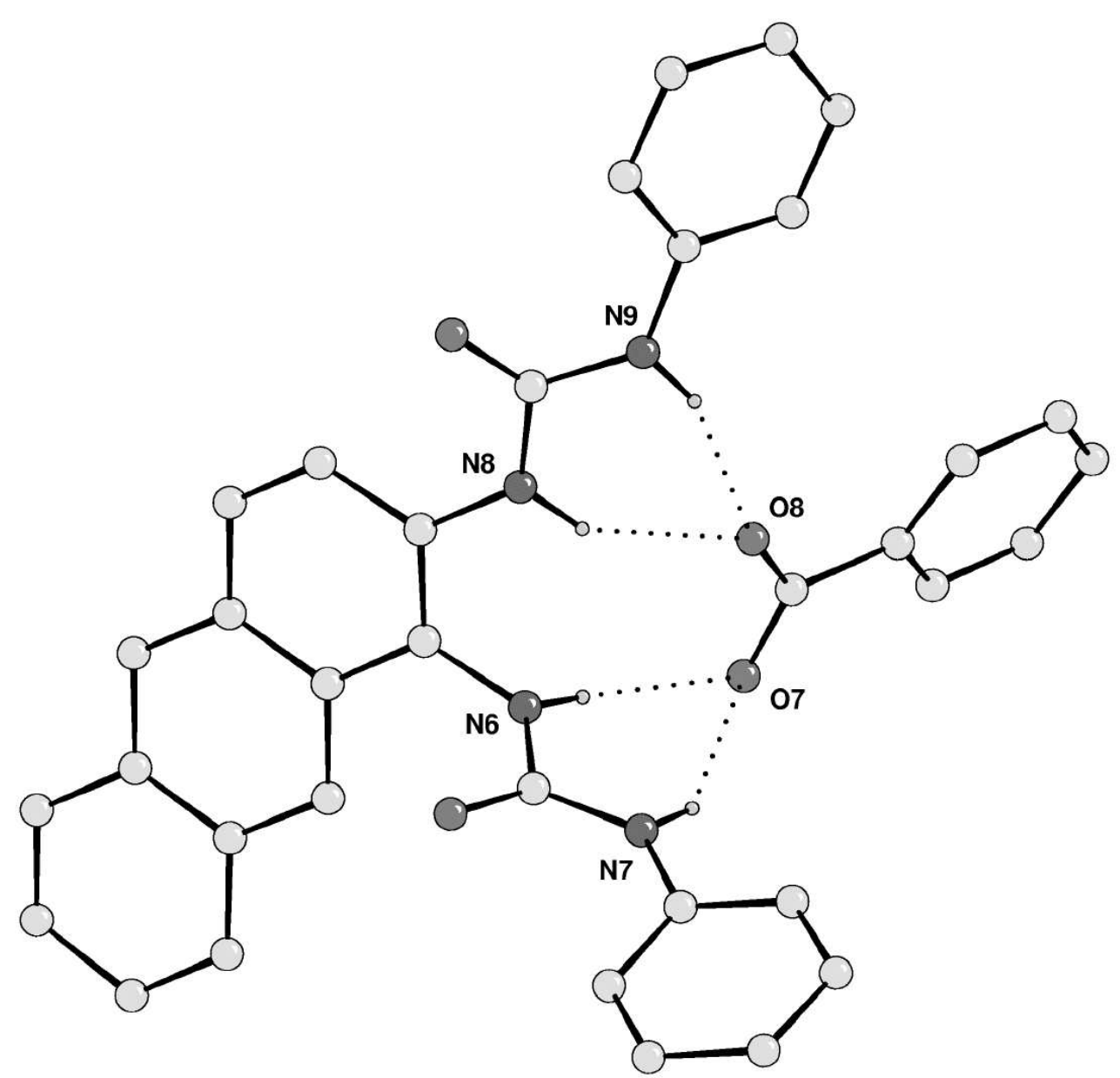

Figure 7 The benzoate complex of 6 showing the formation of four hydrogen bonds between the receptor and the carboxylate anion in the solid state. Tetrabutylammonium counter cations and non-acidic hydrogen atoms omitted for clarity $94 \times 89 \mathrm{~mm}(300 \times 300 \mathrm{DPI})$ 


\title{
Fluorescent Anthracene-based Anion Receptors
}

\author{
Simon J. Brooks ${ }^{\mathrm{a}}$, Claudia Caltagirone, ${ }^{\mathrm{a}}$ Aimee J. Cossins ${ }^{\mathrm{b}}$, Philip A. \\ Gale $^{*^{\mathrm{a}}}$ and Mark Light ${ }^{\mathrm{a}}$ \\ ${ }^{a}$ School of Chemistry, University of Southampton, Southampton, SO17 1BJ, UK \\ ${ }^{b}$ School of Biological Science, University of Southampton, Southampton, SO16 7PX, UK
}

\section{Keywords}

Anion receptors, fluorescence, urea, crystallography

\begin{abstract}
A variety of amide-subsituted anthracene derivates have been synthesised and their anion complexation properties studied using ${ }^{1} \mathrm{H}-\mathrm{NMR}$ titration techniques. Additionally, bis-urea functionalised anthracene derivatives have been shown to serve as excellent receptors for oxo-anions and to function as sensors via fluorescence quenching in DMSO- $\mathrm{d}_{6} / 0.5 \%$ water and MeCN/DMSO $(96.5: 3.5 \mathrm{v} / \mathrm{v})$.
\end{abstract}

\section{Introduction}

The development of simple hydrogen-bond donor anion receptors and sensors is an area of anion complexation that is yet to be fully explored. ${ }^{1}$ In 1997, Crabtree $^{2}$ and Smith $^{3}$ independently discovered that simple isophtalamides function as effective anion receptors. Since this discovery, this motif has been further exploited in the formation of new anion ${ }^{4}$ and ion-pair receptors ${ }^{5}$ along with anion-templated helices ${ }^{6}$, catenanes ${ }^{7}$ and 
rotaxanes. ${ }^{8}$ Similarly, ureas ${ }^{9}$ and thioureas ${ }^{10}$ have been used for anion complexation due to both the relative ease in which they can be synthesized and for their propensity to form strong complexes with oxo-anions such as carboxylates and phosphates. Much effort has also been devoted to the production of anion sensors that combine both an anion binding site and either a chromophore ${ }^{11}$ or a redox active group ${ }^{12}$ that in the presence of a coordinating anion show a perturbation in their optical ot electrochemical properties.

We have recently reported the synthesis of receptors based upon anthraquinone that contain a 'twisted' isophthalamide-like hydrogen-bonding cleft that show an increase in oxo-anion selectivity, relative to non distorted isophthalamides ${ }^{13}$, and also receptors based upon 1,2-phenylenediamine that contain amide or urea groups that can adopt a more planar geometry. ${ }^{14}$ We wished to further investigate the relative merits of each hydrogen bonding motif in terms of both its strength and selectivity of anion coordination in potential anion sensor system that would potentially show a change in fluorescence properties upon the addition of coordinating anions. Previously, numerous research groups have produced anthracene based anion sensors ${ }^{15}$ including those reported by Gunnlaugsson and coworkers that demonstrated high affinities for oxoanions. Therefore receptors 1-4 based upon 1,2- and 1,3-substituted anthracenes were synthesised in an attempt to establish how effective each motif would be at complexing anions in both non-polar and competitive solvent mixtures when appended to an anthracene backbone by means of ${ }^{1} \mathrm{H}-\mathrm{NMR}$ titrations.

We also wished to investigate the use of bis-urea based anthracene receptors as an alternative method for complexing anions. Das and coworkers have demonstrated that bis-urea and bis-thiourea receptors based upon 1,2-diaminoanthraquinone can form 
strong complexes with a variety of anions in MeCN/DMSO (90/10 v/v) solution. ${ }^{16}$ More recently we have demonstrated that in simpler systems based upon 1,2phenylenediamine, carboxylate anions can be coordinated to this type of motif in a 1:1 anion :receptor stoichiometry through four hydrogen bonds with relatively strong stability constants obtained in DMSO/water solvent mixtures. ${ }^{17}$ We hoped similarly strong complexes would be formed with receptors based upon the 1,2diaminoanthracene subunit. For these reasons we synthesised compounds $\mathbf{5}$ and $\mathbf{6}$ and we studied their ability in binding anions by means of ${ }^{1} \mathrm{H}-\mathrm{NMR}$ titrations in DMSO$d_{6} / 0.5 \%$ water and fluorescent titrations both in DMSO and in MeCN/DMSO (96.5:3.5 $v / v)$.

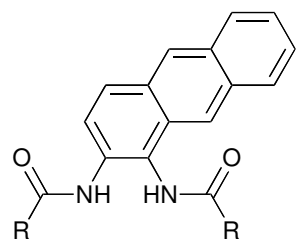

$1 \quad \mathrm{R}=\mathrm{Bu}$

$2 \mathrm{R}=\mathrm{Ph}$

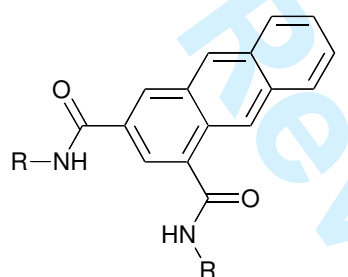

$3 \mathrm{R}=\mathrm{Bu}$

$4 \mathrm{R}=\mathrm{Ph}$

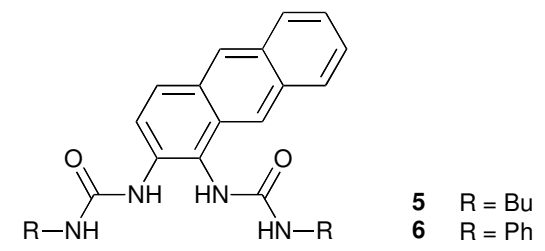




\section{Experimental}

\section{General Methods}

Reagents were purchased from the Aldrich Chemical Co. Deuterated solvents were purchased from Apollo Ltd. Chemical shifts reported in ppm and are referenced to the solvent. Proton and ${ }^{13} \mathrm{C}-\mathrm{NMR}$ spectra were recorded on a Bruker AV-300 NMR spectrometer. UV/vis absorbance spectra were recorded on a Hitachi U-2001 spectrophotometer with fluorescence emission spectra recorded on a Hitachi F-2000 spectrofluorimeter with a $150 \mathrm{~W}$ Xenon lamp. The photomultiplier voltage was set to $400 \mathrm{~V}$ with excitation and emission slits set to $10 \mathrm{~mm}$. Fluorescence titrations were performed by adding to a solution of the receptors $\left(1 \times 10^{-6} \mathrm{M}\right)$ in DMSO and MeCN/DMSO $(96.5 / 3.5 \mathrm{v} / \mathrm{v})$ solutions of anions $\left(2.5 \times 10^{-3} \mathrm{M}\right)$ in a solution of the receptor in order to keep constant the concentration of the receptor during the titration. Luminescence quantum yields were determined using quinine sulphate in $1 \mathrm{M} \mathrm{H}_{2} \mathrm{SO}_{4}$ aqueous solution $(\Phi=0.546)$ as reference.

Elemental analyses were performed by Medac Ltd.

\section{Synthesis}

$N^{1}, N^{2}$-Dibutylanthracene-1,2-dicarboxamide (1).

Anthracene-1,2-diamine $(0.50 \mathrm{~g}, 2.4 \mathrm{mmol})$, triethylamine $(0.74 \mathrm{~mL}, 5.3 \mathrm{mmol})$ and DMAP (a few mg, cat.) were stirred together for 15 minutes in dry DCM (15 mL) before the dropwise addition of valeroyl chloride $(0.56 \mathrm{~mL}, 4.8 \mathrm{mmol})$. The reaction was stirred at ambient temperature under nitrogen for 18 hours. After this time the reaction solvent was washed with water $(3 \times 25 \mathrm{~mL})$ before the remaining solvent was removed in vacuo. The residue was recrystallized from hot ethyl acetate and purified by 
flash column chromatography (90/10 DCM/MeOH v/v), with the product isolated as a yellow/beige solid. Mass of product $=0.35 \mathrm{~g}$. Yield $=39 \% .{ }^{1} \mathrm{H}$ NMR $300 \mathrm{MHz}$ in DMSO- $d_{6} \delta(\mathrm{ppm}): 9.75(\mathrm{~s}, 1 \mathrm{H}, \mathrm{NH}), 9.21(\mathrm{~s}, 1 \mathrm{H}, \mathrm{NH}), 8.57(\mathrm{~s}, 1 \mathrm{H}, \mathrm{ArH}), 8.46(\mathrm{~s}, 1 \mathrm{H}$, ArH), $8.04(\mathrm{~m}, 3 \mathrm{H}, \mathrm{ArH}), 7.80(\mathrm{~d}, 1 \mathrm{H}, \mathrm{J}=9.1 \mathrm{~Hz}, \operatorname{ArH}), 7.52(\mathrm{~m}, 2 \mathrm{H}, \operatorname{ArH}), 2.59(\mathrm{t}$, $\left.2 \mathrm{H}, \mathrm{J}=7.2 \mathrm{~Hz}, \mathrm{CH}_{2}\right), 2.39\left(\mathrm{t}, 2 \mathrm{H}, \mathrm{J}=7.2 \mathrm{~Hz}, \mathrm{CH}_{2}\right), 1.71\left(\mathrm{~m}, 2 \mathrm{H}, \mathrm{CH}_{2}\right), 1.62(\mathrm{~m}, 2 \mathrm{H}$, $\left.\mathrm{CH}_{2}\right), 1.46\left(\mathrm{~m}, 2 \mathrm{H}, \mathrm{CH}_{2}\right), 1.37\left(\mathrm{~m}, 2 \mathrm{H}, \mathrm{CH}_{2}\right), 0.97\left(\mathrm{t}, 3 \mathrm{H}, \mathrm{J}=7.5 \mathrm{~Hz}, \mathrm{CH}_{3}\right), 0.93(\mathrm{t}, 3 \mathrm{H}$, $\left.\mathrm{J}=7.5 \mathrm{~Hz}, \mathrm{CH}_{3}\right) .{ }^{13} \mathrm{C}$ NMR $75.4 \mathrm{MHz}$ in DMSO- $d_{6} \delta(\mathrm{ppm}): 173.6(\mathrm{CO}), 172.83(\mathrm{CO})$, $131.78(\mathrm{C}), 131.3(\mathrm{C}), 130.0(\mathrm{C}), 129.3(\mathrm{C}), 128.4(\mathrm{CH}), 128.0(\mathrm{CH}), 127.8(\mathrm{CH}), 127.6$ $(\mathrm{CH}), 126.8(\mathrm{CH}), 126.0(\mathrm{CH}), 125.8(\mathrm{CH}), 123.7(\mathrm{C}), 123.5(\mathrm{CH}), 121.3(\mathrm{CH}), 37.1$ $\left(\mathrm{CH}_{2}\right), 36.6\left(\mathrm{CH}_{2}\right), 28.3\left(\mathrm{CH}_{2}\right), 27.8\left(\mathrm{CH}_{2}\right), 22.6\left(\mathrm{CH}_{2}\right), 22.5\left(\mathrm{CH}_{2}\right), 14.0\left(\mathrm{CH}_{3}\right), 13.9$ $\left(\mathrm{CH}_{3}\right) . \quad \mathrm{IR}\left(\mathrm{cm}^{-1}\right): 3241,2953,2933,2868,1652,1530,1425,1289,1185,1093,880$, 736. ES- mass spectrem, $m / z, 411.0\left[\mathrm{M}+\mathrm{Cl}^{-}, 489.1[\mathrm{M}+\mathrm{TFA}-\mathrm{H}]^{-}, 787.4[2 \mathrm{M}+\mathrm{Cl}]^{-}\right.$, $865.3[2 \mathrm{M}+\mathrm{TFA}-\mathrm{H}]^{-} . \mathrm{R}_{\mathrm{f}}: 0.56(90: 10 \mathrm{DCM} / \mathrm{MeOH})$. Anal. Found for $\mathrm{C}_{24} \mathrm{H}_{28} \mathrm{~N}_{2} \mathrm{O}_{2}$ (Calcd) (\%) C 76.50 (76.56), H 7.50 (7.50), N 7.42 (7.44)\%. m.p. (DCM/MeOH) $=176$ ${ }^{\circ} \mathrm{C}$.

\section{$N^{1}, N^{2}$-Diphenylanthracene-1,2-dicarboxamide (2).}

Anthracene-1,2-diamine $(0.77 \mathrm{~g}, 3.7 \mathrm{mmol})$, triethylamine $(1.12 \mathrm{~mL}, 8.14$ mmol) and DMAP (a few mg, cat.) were stirred together for 15 minutes in dry DCM (75 mL) before the dropwise addition of benzoyl chloride $(0.86 \mathrm{~mL}, 7.4 \mathrm{mmol})$. The reaction was stirred at ambient temperature under nitrogen for 18 hours after which the precipitated product was removed via filtration and washed with DCM, water and $\mathrm{Et}_{2} \mathrm{O}$. The product was isolated as a yellow powder. Mass of product $=1.26 \mathrm{~g}$. Yield $=82 \%$. ${ }^{1} \mathrm{H}$ NMR $300 \mathrm{MHz}$ in DMSO- $d_{6} \delta(\mathrm{ppm}): 10.42(\mathrm{~s}, 1 \mathrm{H}, \mathrm{NH}), 10.06$ (s, 1H, NH), 8.66 (s, 1H, ArH), 8.59 (s, 1H, ArH), 8.14 (m, 5H, ArH), 7.92 (m, 3H, ArH), 7.57 (m, 8H, 
ArH). ${ }^{13} \mathrm{C}$ NMR $75.4 \mathrm{MHz}$ in DMSO- $d_{6}$ [in the presence of 5 equivalents TBACl] $\delta$ (ppm): $165.7(\mathrm{CO}), 165.0(\mathrm{CO}), 133.9(\mathrm{C}), 131.8(\mathrm{CH}), 131.8(\mathrm{CH}), 131.2(\mathrm{CH}), 129.8$ (C), $128.7(\mathrm{C}), 128.4(\mathrm{CH}), 128.3(\mathrm{CH}), 128.1(\mathrm{CH}), 127.8(\mathrm{CH}), 127.7(\mathrm{CH}), 126.9$ $(\mathrm{CH}), 16.3(\mathrm{CH}), 125.8(\mathrm{CH}), 125.5(\mathrm{CH}), 124.7(\mathrm{CH}), 122.5(\mathrm{CH}), 57.54\left(\mathrm{TBA} \mathrm{CH}_{2}\right)$, $23.1\left(\mathrm{TBA} \mathrm{CH}_{2}\right), 19.2\left(\mathrm{TBA} \mathrm{CH}_{2}\right), 13.4(\mathrm{TBA} \mathrm{CH}) . \mathrm{IR}\left(\mathrm{cm}^{-1}\right): 3247,3037,1647$, 1519, 1459, 1289, 894. LRMS ES- mass spectrum, $m / z, 450.9[\mathrm{M}+\mathrm{Cl}]^{-}, 529.0[\mathrm{M}+$ TFA - H] $]^{-}, 945.7[2 \mathrm{M}+\text { TFA - H] }]^{-}$. Anal. Found for $\mathrm{C}_{28} \mathrm{H}_{20} \mathrm{~N}_{2} \mathrm{O}_{2}+0.40 \mathrm{CH}_{2} \mathrm{Cl}_{2}(\mathrm{Calcd})$ C 75.98 (75.73), H 4.63 (4.65), N 6.22 (6.22)\%. m.p. $\left(\mathrm{Et}_{2} \mathrm{O}\right)=$ decomp. $251-255^{\circ} \mathrm{C}$.

\section{$N^{1}, N^{3}$-Dibutylanthracene-1,3-dicarboxamide (3).} n-Butylamine (0.43 mL, $4.4 \mathrm{mmol})$ was dissolved in dry DCM (25 mL). Trimethylaluminium solution $(2 \mathrm{M})$ in hexane $(2.2 \mathrm{~mL}, 4.4 \mathrm{mmol})$ was added dropwise to the solution and the mixture stirred for 30 minutes. 1,3-Anthracenedimethyl ester (0.64 g, $2.2 \mathrm{mmol}$ ) was added and the reaction heated at reflux for 5 days. The reaction mixture was allowed to cool and aqueous $\mathrm{HCl}$ solution $(1: 10 \mathrm{v} / \mathrm{v})$ added until bubbling ceased. A further $50 \mathrm{~mL}$ of water was added and the reaction was stirred for a further 30 minutes. The reaction mixture was washed with water $(3 \times 50 \mathrm{~mL})$ and the organic phase containing the suspended compound retained. The remaining solvent was removed in vacuo and the residue dried under high vacuum. The product was isolated as a pale yellow solid. Mass of product $=0.26 \mathrm{~g}$. Yield $=32 \% .{ }^{1} \mathrm{H}$ NMR $300 \mathrm{MHz}$ in $\mathrm{CDCl}_{3}-d_{1} \delta(\mathrm{ppm}): 8.65(\mathrm{~s}, 1 \mathrm{H}, \mathrm{NH}), 8.02(\mathrm{~s}, 1 \mathrm{H}, \mathrm{NH}), 7.99(\mathrm{~s}, 1 \mathrm{H}, \mathrm{ArH}), 7.86(\mathrm{~d}, 1 \mathrm{H}, \mathrm{J}$ $=8.4 \mathrm{~Hz}, \operatorname{ArH}), 7.68(\mathrm{~d}, 1 \mathrm{H}, \mathrm{J}=8.4 \mathrm{~Hz}, \operatorname{ArH}), 7.62(\mathrm{~d}, 1 \mathrm{H}, \mathrm{J}=1.1 \mathrm{~Hz}, \operatorname{ArH}), 7.40(\mathrm{~m}$, 2H, ArH), 6.79 (m, 2H, ArH), 3.50 (q, 2H, J = 7.0 Hz, $\left.\mathrm{CH}_{2}\right), 3.40$ (q, 2H, J = $6.9 \mathrm{~Hz}$, $\mathrm{CH}_{2}$ ), $1.64\left(\mathrm{~m}, 4 \mathrm{H}\right.$, overlapping $\left.\mathrm{CH}_{2}\right), 1.43\left(\mathrm{~m}, 4 \mathrm{H}\right.$, overlapping $\left.\mathrm{CH}_{2}\right), 0.97(\mathrm{~m}, 6 \mathrm{H}$, overlapping $\mathrm{CH}_{3}$ ). ${ }^{13} \mathrm{C} \mathrm{NMR} 75.4 \mathrm{MHz}$ in $\mathrm{CDCl}_{3}-d_{1} \delta$ (ppm): $169.3(\mathrm{CO}), 167.4(\mathrm{CO})$, 
$134.9(\mathrm{C}), 133.0(\mathrm{C}), 131.8(\mathrm{C}), 130.3(\mathrm{C}), 130.0(\mathrm{CH}), 129.9(\mathrm{C}), 128.7(\mathrm{CH}), 128.3$ (C), $128.2(\mathrm{CH}), 128.0(\mathrm{CH}), 126.6(\mathrm{CH}), 126.3(\mathrm{CH}), 124.6(\mathrm{CH}), 122.2(\mathrm{CH}), 40.2$ $\left(\mathrm{CH}_{2}\right), 40.0\left(\mathrm{CH}_{2}\right), 31.8\left(\mathrm{CH}_{2}\right), 20.4\left(\mathrm{CH}_{2}\right), 13.9\left(\mathrm{CH}_{3}\right) . \mathrm{IR}\left(\mathrm{cm}^{-1}\right):$ 3247, 2954, 1654, $1624,1553,1294,1250,1157,875,733$. ES- mass spectrum, $m / z, 489.0(\mathrm{M}+\mathrm{TFA}-$ $\mathrm{H})^{-}, 865.2(2 \mathrm{M}+\mathrm{TFA}-\mathrm{H})^{-}$. Anal. Found for $\mathrm{C}_{24} \mathrm{H}_{28} \mathrm{~N}_{2} \mathrm{O}_{2}+0.17 \mathrm{CH}_{2} \mathrm{Cl}_{2}$ (Calcd) $\mathrm{C}$ 74.23 (74.30), H 7.41 (7.31), N 7.15 (7.17)\%. m.p. $\left(\mathrm{H}_{2} \mathrm{O}\right)=173^{\circ} \mathrm{C}$.

$N^{1}, N^{3}$-Diphenylanthracene-1,3-dicarboxamide (4).

Aniline (0.54 g, $5.8 \mathrm{mmol})$ was dissolved in dry DCM (30 mL). Trimethylaluminium solution $(2 \mathrm{M})$ in hexane $(2.9 \mathrm{~mL}, 5.8 \mathrm{mmol})$ was added dropwise and the solution stirred for 30 minutes. 1,3-Anthracenedimethyl ester $(0.85 \mathrm{~g}, 2.9 \mathrm{mmol})$ was added and the mixture heated at reflux for 5 days. The reaction mixture was allowed to cool and aqueous $\mathrm{HCl}$ solution (1:10 v/v) added carefully until bubbling ceased. A further $75 \mathrm{~mL}$ of water was added and the reaction was stirred for 30 minutes before the reaction mixture was washed with water $(3 \times 50 \mathrm{~mL})$ and the organic phase containing the suspended compound retained. The organic phase was reduced in vacuo and the compound dried under high vacuum. Product was isolated as a pale yellow solid. Mass of product $=0.99 \mathrm{~g}$. Yield $=82 \% .{ }^{1} \mathrm{H}$ NMR $300 \mathrm{MHz}$ in DMSO $-d_{6} \delta$ (ppm): 10.77 (s, 1H, NH), 10.56 (s, 1H, NH), 8.92 (m, 2H, ArH), 8.89 (m, 1H, ArH), $8.20(\mathrm{~m}, 2 \mathrm{H}, \mathrm{ArH}), 7.87$ (m, 4H, ArH), 7.61 (m, 2H, ArH), 7.40 (m, 4H, ArH), 7.16 (m, $2 \mathrm{H}, \mathrm{ArH}) .{ }^{13} \mathrm{C}$ NMR $75.4 \mathrm{MHz}$ in DMSO- $d_{6} \delta(\mathrm{ppm}): 166.9(\mathrm{CO}), 164.8(\mathrm{CO}), 139.3$ (C), $139.1(\mathrm{C}), 134.8$ (C), $132.6(\mathrm{C}), 131.6(\mathrm{C}), 131.2(\mathrm{CH}), 130.3(\mathrm{C}), 130.3(\mathrm{C}), 128.8$ $(\mathrm{CH}), 128.7(\mathrm{CH}), 128.6(\mathrm{CH}), 128.1(\mathrm{CH}), 127.0(\mathrm{CH}), 126.5(\mathrm{CH}), 124.2(\mathrm{CH}), 123.9$ $(\mathrm{CH}), 123.5(\mathrm{CH}), 120.5(\mathrm{CH}), 120.0(\mathrm{CH}) . \quad$ IR $\left(\mathrm{cm}^{-1}\right): 3274,3126,1638,1594,1526$, $1491,1317,1247,893,865$. ES- mass spectrum. $m / z, 529.0(\mathrm{M}+\text { TFA - H })^{-}, 945.1(2 \mathrm{M}$ 
+ TFA - H $)^{-}, 1362.9(3 \mathrm{M}+\text { TFA - H) })^{-}$Anal. Found for $\mathrm{C}_{28} \mathrm{H}_{20} \mathrm{~N}_{2} \mathrm{O}_{2}+0.20 \mathrm{CH}_{3} \mathrm{CN}$ (Calcd) C 80.02 (80.32), H 4.81 (4.89), N 6.92 (7.16)\%. m.p. $\left(\mathrm{H}_{2} \mathrm{O}\right)=$ decomp. 243-248 ${ }^{\circ} \mathrm{C}$.

\section{1,2-Anthracene bis-butylurea (5).}

Anthracene-1,2-diamine $(0.20 \mathrm{~g}, 1.0 \mathrm{mmol})$ was dissolved in dry DCM (40 mL) and butylisocyanate $(0.22 \mathrm{~mL}, 2.0 \mathrm{mmol})$ added dropwise. The reaction was stirred at ambient temperature for 18 hours. The solvent was removed in vacuo and the residue redisolved in 90:10 DCM:MeOH and purified by flash column chromatography. The product was further purified by recrystalisation from EtOH. The product was obtained as a brown solid. Mass of product $=0.21 \mathrm{~g}$. Yield $=54 \% .{ }^{1} \mathrm{H}$ NMR $300 \mathrm{MHz}$ in DMSO- $d_{6} \delta(\mathrm{ppm}): 8.49(\mathrm{~s}, 1 \mathrm{H}, \mathrm{NH}), 8.20(\mathrm{~m}, 2 \mathrm{H}, \mathrm{NH} \& \mathrm{ArH}), 7.92(\mathrm{~m}, 4 \mathrm{H}, \mathrm{ArH})$, $7.46(\mathrm{~m}, 2 \mathrm{H}, \mathrm{ArH}), 7.08(\mathrm{t}, 1 \mathrm{H}, \mathrm{J}=5.1 \mathrm{~Hz}, \mathrm{NH}), 6.30($ br s, 1H, NH), $3.12(\mathrm{~m}, 4 \mathrm{H}$, $\left.\mathrm{CH}_{2}\right), 1.45\left(\mathrm{~m}, 4 \mathrm{H}, \mathrm{CH}_{2}\right), 1.34\left(\mathrm{~m}, 4 \mathrm{H}, \mathrm{CH}_{2}\right), 0.90\left(\mathrm{~m}, 6 \mathrm{H}, \mathrm{CH}_{3}\right) .{ }^{13} \mathrm{C} \mathrm{NMR} 75.4 \mathrm{MHz}$ in DMSO- $d_{6} \delta(\mathrm{ppm}): 15.7 .0(\mathrm{CO}), 155.2(\mathrm{CO}), 131.3(\mathrm{C}), 130.1(\mathrm{C}), 129.9(\mathrm{C}), 128.6$ (C), $127.9(\mathrm{CH}), 127.7(\mathrm{CH}), 126.4(\mathrm{CH}), 126.2(\mathrm{CH}), 125.7(\mathrm{CH}), 124.8(\mathrm{CH}), 122.3$ $(\mathrm{CH}), 120.0(\mathrm{CH}), 39.22\left(\mathrm{CH}_{2}\right), 38.9\left(\mathrm{CH}_{2}\right), 32.0\left(\mathrm{CH}_{2}\right), 31.8\left(\mathrm{CH}_{2}\right), 19.6\left(\mathrm{CH}_{2}\right), 19.5$ $\left(\mathrm{CH}_{2}\right), 13.7\left(\mathrm{CH}_{3}\right), 13.6\left(\mathrm{CH}_{3}\right) . \mathrm{IR}\left(\mathrm{cm}^{-1}\right): 3268,2953,2924,2858,1637,1561,1458$, 1239, 882, 741. ES- mass spectrum, $m / z, 441.5[\mathrm{M}+\mathrm{Cl}]^{-}, 519.5[\mathrm{M}+\mathrm{TFA}-\mathrm{H}]^{-}, 848.4$ $[2 \mathrm{M}+\mathrm{Cl}]^{-}$, Anal. Found for $\mathrm{C}_{24} \mathrm{H}_{30} \mathrm{~N}_{4} \mathrm{O}_{2}$ (Calcd) $\mathrm{C} 70.61$ (70.91), $\mathrm{H} 7.35$ (7.44), N $13.58(13.78) \%$. m.p. $($ EtOH $)=$ decomp. $186-188^{\circ} \mathrm{C}$.

\section{1,2-Anthracene bis-phenylurea (6).}

Anthracene-1,2-diamine (0.35 g, $1.7 \mathrm{mmol})$ was dissolved in dry DCM (40 mL) and phenylisocyanate $(0.37 \mathrm{~mL}, 3.4 \mathrm{mmol})$ added dropwise. The reaction was left stirring at ambient temperature for 18 hours. The precipitated product was removed by 
filtration and the residue washed with $\mathrm{DCM}(3 \times 10 \mathrm{~mL})$ and $\mathrm{MeOH}(3 \times 10 \mathrm{~mL})$. Product was isolated as a green solid. Mass of product $=0.37 \mathrm{~g}$. Yield $=49 \% .{ }^{1} \mathrm{H}$ NMR $300 \mathrm{MHz}$ in DMSO- $d_{6} \delta(\mathrm{ppm}): 9.50(\mathrm{~s}, 1 \mathrm{H}, \mathrm{NH}), 9.15(\mathrm{~s}, 1 \mathrm{H}, \mathrm{NH}), 8.57(\mathrm{~s}, 1 \mathrm{H}, \mathrm{NH})$, $8.28(\mathrm{~d}, 2 \mathrm{H}, \mathrm{J}=8.8 \mathrm{~Hz}, \operatorname{ArH}), 8.09-8.01(\mathrm{~m}, 3 \mathrm{H}, \operatorname{ArH} \& \mathrm{NH}), 7.52-7.45(\mathrm{~m}, 6 \mathrm{H}, \operatorname{ArH})$, $7.29(\mathrm{t}, 4 \mathrm{H}, \mathrm{J}=7.3 \mathrm{~Hz}), 6.98(\mathrm{td}, 2 \mathrm{H}, \mathrm{J}=7.3 \& 0.7 \mathrm{~Hz}, \mathrm{ArH}) .{ }^{13} \mathrm{C} \mathrm{NMR} 75.4 \mathrm{MHz}$ in DMSO- $d_{6} \delta$ (ppm): $154.1(\mathrm{CO}), 152.7$ (CO), $140.1(\mathrm{C}), 139.7(\mathrm{C}), 133.8(\mathrm{C}), 131.5$ (C), $130.2(\mathrm{C}), 129.9(\mathrm{C}), 128.8(\mathrm{CH}), 128.7(\mathrm{CH}), 127.9(\mathrm{CH}), 126.9(\mathrm{CH}), 126.4(\mathrm{CH})$, $125.9(\mathrm{CH}), 122.4(\mathrm{CH}), 121.9(\mathrm{CH}), 121.7(\mathrm{CH}), 120.1(\mathrm{CH}), 119.9(\mathrm{C}), 118.3(\mathrm{CH})$, $118.2(\mathrm{CH}) . \quad$ IR $\left(\mathrm{cm}^{-1}\right): 3261,3045,1598,1563,1443,1313,1222,874,727$. ES- mass spectrum, $m / z, 559.3[\mathrm{M}+\mathrm{TFA}-\mathrm{H}]^{-}, 927.6[2 \mathrm{M}+\mathrm{Cl}]^{-}, 1005.0[2 \mathrm{M}+\mathrm{TFA}-\mathrm{H}]^{-}$, $1373.7[3 \mathrm{M}+\mathrm{Cl}]$. Anal. Found for $\mathrm{C}_{24} \mathrm{H}_{28} \mathrm{~N}_{2} \mathrm{O}_{2}+0.25 \mathrm{CH}_{2} \mathrm{Cl}_{2}$ (Calcd) $\mathrm{C} 72.48$ (72.54), H 5.07 (4.85), N 11.70 (11.98)\%. m.p. (DCM /MeOH) = decomp. 261-264 ${ }^{\circ} \mathrm{C}$.

\section{Crystallography}

Crystal data for $1 \mathrm{C}_{24} \mathrm{H}_{28} \mathrm{~N}_{2} \mathrm{O}_{2}, \mathrm{Mr}=376.48, \mathrm{~T}=120(2) \mathrm{K}$, monoclinic, space group

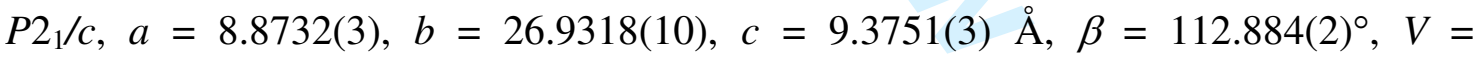
2064.05(12) $\AA^{3}, \rho_{\text {calc }}=1.212 \mathrm{~g} \mathrm{~cm}^{-3}, \mu=0.077 \mathrm{~mm}^{-1}, \mathrm{Z}=4$, reflections collected: 22715 , independent reflections: $4700\left(R_{\text {int }}=0.0742\right)$, final $R$ indices $[I>2 \sigma I]: R 1=$ $0.0600, w R 2=0.1355, R$ indices (all data): $R 1=0.1322 . w R 2=0.1621$. CCDC 631103 .

Crystal data for the benzoate complex of $5 \mathrm{C}_{47} \mathrm{H}_{71} \mathrm{~N}_{5} \mathrm{O}_{4}, \mathrm{Mr}=770.09 .48, \mathrm{~T}=120$ (2) $\mathrm{K}$, monoclinic, space group $P 2{ }_{1} / c, a=17.0539(11), b=8.8884(4), c=30.0050(17) \AA, \beta=$ 96.399(2) $)^{\circ}, V=4519.9(4) \AA^{3}, \rho_{\text {calc }}=1.132 \mathrm{~g} \mathrm{~cm}^{-3}, \mu=0.072 \mathrm{~mm}^{-1}, \mathrm{Z}=4$, reflections collected: 40230, independent reflections: $9618\left(R_{\text {int }}=0.1179\right)$, final $R$ indices $[I>$ $2 \sigma I$ ] $R 1=0.1282, w R 2=0.3284, R$ indices (all data): $R 1=0.2582 . w R 2=0.3922$. CCDC 631102. 
Crystal data for the benzoate complex of $6 \mathrm{C}_{51} \mathrm{H}_{63} \mathrm{~N}_{5} \mathrm{O}_{4}, \mathrm{Mr}=810.06, \mathrm{~T}=120(2) \mathrm{K}$, Monoclinic, space group $P 2_{1} / c, a=37.6085(19), b=23.5672(12), c=10.1095(3) \AA$, $\beta=92.486(3)^{\circ}, V=8951.9(7) \AA^{3}, \rho_{\text {calc }}=1.202 \mathrm{~g} \mathrm{~cm}^{-3}, \mu=0.076 \mathrm{~mm}^{-1}, Z=8$, reflections collected: 37072, independent reflections: $15003\left(R_{\text {int }}=0.1132\right)$, final $R$ indices $[I>2 \sigma I]: R 1=0.1561, w R 2=0.2578, R$ indices (all data): $R 1=0.2795 . w R 2$ $=0.3252$. CCDC 631101 .

\section{Results and Discussion}

Compounds $\mathbf{1}$ and $\mathbf{2}$ were synthesised from an acid chloride condensation reaction between 1,2-diaminoanthracene ${ }^{18}$ and valeroyl and benzoyl chloride in the presence of triethylamine and a catalytic quantity of DMAP to afford the products in $39 \%$ and $82 \%$ respective yields. Receptors 3 and $\mathbf{4}$ were synthesised by reaction of the 1,3-dimethyl anthracenedicarboxylate $^{19}$ and either $n$-butylamine or aniline in the presence of trimethylaluminium solution $2 \mathrm{M}$ in dry dichloromethane that afforded the products in 32 and $82 \%$ respective yields. Compounds 5 and $\mathbf{6}$ were synthesized from 1,2diaminoanthracene and butylisocyanate or phenylisocyanate yielding the two products in $54 \%$ and $49 \%$ yield respectively.

X-ray quality crystals of $\mathbf{1}$ were obtained via slow evaporation of an acetonitrile solution of the compound. As shown in Figure 1, in the solid-state, the receptor forms an infinite hydrogen bonded chain with bonding interactions between the amide NH groups and the carbonyl groups of an adjacent molecule of 1 [N $\cdots$ O 2.844(2) and 2.910(2) $\AA$ ]. The structure indicates that both amide NH groups are able to adopt an almost parallel geometry in the solid state and therefore may facilitate the coordination of oxo-anions separate interactions to different oxygen atoms in the anion. 
The presence of the butyl groups in $\mathbf{1}$ and $\mathbf{3}$ conferred solubility on these compounds in weakly coordinating dichloromethane (DCM) solution. It was therefore decided to initially investigate the anion binding properties of $\mathbf{1}$ and $\mathbf{3}$ in DCM- $d_{2}$ using ${ }^{1} \mathrm{H}$ NMR titration techniques (Table 1).

Compound 1 was found to possess a slightly higher oxo-anion affinity than compound 3 under these solvent conditions however, overall the affinity of the two compounds for anionic guests was very similar. In order to provide greater insight into the anion binding behaviour of receptors $\mathbf{1}$ and $\mathbf{3}$ and to evaluate the properties of aryl functionalized receptors 2 and $\mathbf{4}$, further ${ }^{1} \mathrm{H}-\mathrm{NMR}$ titration experiments were performed in the more competitive solvent mixture of DMSO- $d_{6} / 0.5 \%$ water (Table 2). As expected, in, with the exception of dihydrogen phosphate all of the anions are bound more weakly. Interestingly the halide selectivity displayed by isophthalamide type receptor 3 in dichloromethane is not observed in DMSO- $d_{6} / 0.5 \%$ water, with both phosphate and carboxylate anions bound more strongly in this solvent mixture. Compound 4 displays the highest observed stability constant with dihydrogen phosphate of $122 \mathrm{M}^{-1}$, consistent with the increase in acidity of the amide $\mathrm{NH}$ groups relative to alkyl derivative 3 .

Anion stability constants with compounds 5 and $\mathbf{6}$ were also elucidated via ${ }^{1} \mathrm{H}-\mathrm{NMR}$ titration experiments performed in DMSO- $d_{6} / 0.5 \%$ water revealing a significant increase in the values obtained for compounds 1-4 under the same conditions, however a similar trend of oxo-anion selectivity was observed (Table 3). Of the two compounds the bis-phenylurea 6 displayed stability constants approaching an order of magnitude higher than those of 5 (c.f. acetate 277 vs $2540 \mathrm{M}^{-1}$ ) presumably arising from the greater acidity of the outer urea NH protons of receptor 6 due to the presence of the 
electron-withdrawing aryl substituents. The titration curves for this compound are shown in Figure 2.

Because receptors 5 and $\mathbf{6}$ formed complexes with considerably improved stability with respect to those formed by compounds $\mathbf{1 - 4}$, we decided to investigate the photophysical properties of these systems to determine their effectiveness as fluorescent anion sensors. Fluorescence titrations were performed both in DMSO and in the relatively non-competitive MeCN/DMSO (96.5/3.5 v/v) solvent mixture. The UV/vis absorbance spectra of compounds 5 and $\mathbf{6}$ in DMSO both display similar characteristic shapes, with maximum absorbances centred at $370\left(\varepsilon=4600 \mathrm{dm}^{3} \mathrm{~mol}^{-1} \mathrm{~cm}^{-1}\right)$ and $368 \mathrm{~nm}(6300$ $\mathrm{dm}^{3} \mathrm{~mol}^{-1} \mathrm{~cm}^{-1}$ ) respectively. Excitation of the compounds at these wavelengths provided maximum fluorescent emission peaks that were broad in appearance and centred at 493 and $477 \mathrm{~nm}$ respectively. The two receptors show very good fluorescence quantum yields ( $\Phi=0.44$ and 0.50 for $\mathbf{5}$ and $\mathbf{6}$, respectively). The effect of increasing concentration of coordinating oxo-anions in the form of their tetrabutylammonium salts upon the fluorescent emission of both receptors $\mathbf{5}$ and $\mathbf{6}$ was investigated. Whilst only relatively small changes in the UV/vis absorbance spectra were recorded, a significant reduction in the fluorescence emission was observed (Figures 3 and 4) when a large excess of anion (up to 300 equivalents) was added to the solution of both compounds $\mathbf{5}$ and $\mathbf{6}$ in DMSO. We decided to repeat the titrations in a mixture of MeCN/DMSO (96.5/3.5 $v / v)$ and found that the absorption and emission properties of both ligands were similar to those observed in DMSO. We recorded the fluorescence emission exciting both the compounds at $362 \mathrm{~nm}$ and found that the maximum emission was at 458 and $465 \mathrm{~nm}$ for receptors 5 and 6 respectively. In the case of receptor $\mathbf{6}$ a partial quenching of the fluorescence emission was evident with 
acetate $\left(\mathrm{I}_{r e s}=21 \%\right)$ and in less extent with benzoate $\left(\mathrm{I}_{\text {res }}=53 \%\right)$, dihydrogen phosphate $\left(\mathrm{I}_{r e s}=70 \%\right)$ and chloride $\left(\mathrm{I}_{\text {res }}=96 \%\right)$ upon addition of 30 equivalents of anions (Figure 5). For receptor 5 we did not observed any significant changes in the fluorescence emission upon addition of anions (see Supplementary Informations).

Slow evaporation of an acetonitrile solution of $\mathbf{5}$ in the presence of excess tetrabutylammonium benzoate yielded X-ray quality crystals of the complex. The benzoate anion is bound by the receptor through four hydrogen bonds with both the inner urea $\mathrm{NH}$ groups $[\mathrm{N}$. . O 2.851(6) and 2.839(6) $\AA$ ] and external urea NH groups [N. . O 2.890(6) and 2.830(6) $\AA$ ] coordinating both of the oxygen atoms of the anion (Figure 6).

Similarly, slow evaporation of an acetonitrile solution of $\mathbf{6}$ in the presence of excess tetrabutylammonium benzoate yielded X-ray quality crystals of the complex. The benzoate anion is bound by the receptor via four hydrogen bonds with both the inner

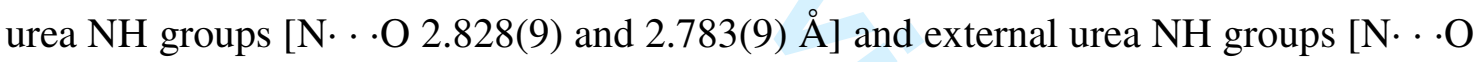
2.837(10) and 3.074(9) $\AA$ ] coordinating both of the oxygen atoms of the anion (Figure 7).

\section{Conclusions}

The variation of the hydrogen bonding motifs of bis-amide receptors allows the selectivity to be tuned to a certain extent in weakly coordinating dichloromethane solution. However in DMSO solution there is little difference between the anion affinity of the two motifs studied. The bis-urea motif forms stronger complexes with oxo-anions under more competitive conditions due to the ability of the receptors to form up to four simultaneous hydrogen bonds to the anion. The incorporation of an 
anthracene fluorophore enables the receptor to function as a sensor for carboxylate anions with a good selectivity in a mixture of MeCN/DMSO (96.5/3.5 v/v). We are currently investigating alternative methods of incorporating the bis-urea motif into both optical and electrochemical sensors, the results of which will be published in due course.

\section{Acknowledgements}

We would like to thank the EPSRC for a DTA studentship (SJB) and the EPSRC together with Professor Mike Hursthouse for use of the crystallographic facilities at the University of Southampton. We would also like to thank Professor Mike Gore for the use of fluoroscence facilities at the school of Biological Sciences at the University of Southampton. CC would like to thank Regione Sardegna for a Master \& Back grant.

References

[1] Sessler, J.L.; Gale P.A.; Cho, W.-S. Anion Receptor Chemistry Ed. Stoddart, J.F. RSC Cambridge 2006; Schmidtchen F.P.; Berger, M. Chem. Rev. 1997, 97, 1609; Gale P.A., Acc. Chem. Res. 2006, 39, 465; Gale, P.A. Chem. Commun. 2005, 3761; Bowman-James, K. Acc. Chem. Res. 2005, 38, 671 ; Gale, P.A. ; Quesada, R. Coord. Chem. Rev. 2006, 250, 3219.

[2] Kavallieratos, K.; de Gala, S. R.; Austin D. J.; Crabtree R. H., J. Am. Chem. Soc., 1997, 119, 2325.

[3] Hughes M. P.; Smith, B. D. J. Org. Chem., 1997, 62, 4492.

[4] Brooks, S. J.; Gale P.A.; Light, M.E. Chem. Commun., 2006, 4344; Hossain, M.A.; Llinares, J. M.; Powell D.; Bowman-James, K. Inorg. Chem., 2001, 40, 
2936; Sessler, J.L.; Katayev, E.;. Pantos, G.D.; Scherbakov P.; Reshetova, M.D. J. Am. Chem. Soc., 2005, 126, 11442; Santacroce, P.V.; Davis, J.T.; Light, M.E.; Gale, P.A.; Iglesias-Sánchez, J.C.; Prados, P.; Quesada, R. J. Am. Chem. Soc. 2007, DOI: 10.1021/ja068067v; Brooks, S.J., García-Garrido, S.E.; Light, M.E.; Cole, P.A.; Gale, P.A. Chem. Eur. J. 2007, in press.

[5] Deetz, M.J.; Shang M.; Smith, B.D. J. Am. Chem. Soc., 2000, 122, 6201; Mahoney, J. M.; Beatty A.; Smith, B. D. J. Am. Chem. Soc., 2001, 123, 5847.

[6] Coles, S.J.; Frey, J. G.; Gale, P.A.; Hursthouse, M.B.; Light, M.E.; Navakhun K.; Thomas, G. L. Chem. Commun., 2003, 568.

[7] Sambrook, M.R.; Beer, P.D.; Wisner, J.A.; Paul R.L.; Cowley, A. R. J. Am. Chem. Soc., 2004, 126, 15364.

[8] Blight, B.A.; Wisner J.A.; Jennings, M.C. Chem. Commun., 2006, 4593.

[9] Bühlmann, P.; Nishizawa, S.; Xiao K. P.; Umezawa, Y. Tetrahedron., 1997, 53, 1647; Snellink-Ruël, B.H.M.; Antonisse, M.M.G.; Engbersen, J.F.J.; Timmerman P.; Reinhoudt, D. N. Eur. J. Org. Chem. 2000, 165; Amedola, V.; Boiocchi, M.; Esteban-Gómez, D.; Fabbrizzi L.; Monzani, E. Org. Biomol. Chem. 2005, 3, 2632; García-Garrido, S.E.; Caltagirone, C.; Light, M.E.; Gale, P.A. Chem. Commun. 2007, 10.1039/b618072h.

[10] Kyne, G. M.; Light, M. E.; Hursthouse, M.B.; de Mendoza J.; Kilburn, J.D. J. Chem. Soc., Perkin Trans. 1. 2001, 1258.

[11] Jiménez, D.; Martínez-Máñez, R.; Sancenón F.; Soto, J. Tetrahedron Lett., 2002, 43, 2823.

[12] Otón, F.; Tárraga, A.; Espinosa, A.; Velasco M. D.; Molina, P. J. Org. Chem., 2006, 71, 4590; Pratt M. D.; Beer, P. D. Polyhedron., 2003, 22, 649. 
[13] Brooks, S.J.; Evans, L.S.; Gale, P.A.; Hursthouse M.B.; Light M.E., Chem. Commun., 2005, 734.

[14] Brooks, S. J.; Gale, P. A.; Light, M. E., Chem. Commun., 2005, 4696.

[15] Gunnlaugsson, T.; Davis, A. P.; O'Brien, J. E.; Glynn, M., Org. Lett., 2002, 4, 2449 and references cited therein; Mei M.; Wu, S. New. J. Chem., 2001, 25, 471.

[16] Jose, D. A.; Kumar, D. K.; Ganguly B.; Das A.Tetrahedron Lett., 2005, 46, 5343.

[17] Brooks, S. J. Edwards, P. R.; Gale P. A. and Light, M. E. New. J. Chem., 2006, 30, 65; Brooks, S. J.; Gale P. A.; Light, M. E., CrystEngComm, 2005, 7, 5864.

[18] van Hove, M. Bull. Soc. Chim. Belg., 1957, 66, 438.

[19] Sukharevsky, A. P.; Read, I.; Linton, B.; Hamilton, A.D.; Waldeck, D. H. J. Phys. Chem. B., 1998, 102, 5394.

[20] Hynes, M. J. Dalton Trans., 1993, 311.

Figure 1. Receptor 1 forms hydrogen-bonded chains in the solid state. Non-acidic hydrogen atoms have been omitted for clarity.

Figure 2. Shifts of the central urea $\mathrm{NH}$ groups of compound 6 upon the addition of tetrabutylammonium salts in DMSO- $d_{6} / 0.5 \%$ water. 
Figure 3. Fluorescence quenching of $\mathbf{6}$ in DMSO upon the addition of tetrabutylammonium acetate.

Figure 4. Fluorescence solutions of compound 6 in DMSO illuminated at $365 \mathrm{~nm}$ (from left to right) in the absence of an anionic guest, in the presence of an excess of $\mathrm{TBAH}_{2} \mathrm{PO}_{4}$, TBAOAc and TBAOBz.

Figure 5. Fluorescence intensity/molar ratio plots for $6\left[1 \times 10^{-6} \mathrm{M}\right.$, MeCN/DMSO $(96.5 / 3.5 \mathrm{v} / \mathrm{v})]$ in the presence of increasing amounts of $\mathrm{AcO}^{-}(\diamond), \mathrm{H}_{2} \mathrm{PO}_{4}^{-}(\triangle), \mathrm{BzO}^{-}$ (匹) and $\mathrm{Cl}^{-}(+)$.

Figure 6 The benzoate complex of $\mathbf{5}$ showing the formation of four hydrogen bonds between the receptor and the carboxylate anion in the solid state. Tetrabutylammonium counter cations and non-acidic hydrogen atoms omitted for clarity.

Figure 7 The benzoate complex of $\mathbf{6}$ showing the formation of four hydrogen bonds between the receptor and the carboxylate anion in the solid state. Tetrabutylammonium counter cations and non-acidic hydrogen atoms omitted for clarity 
Table 1 Stability constants $\left(\mathrm{M}^{-1}\right)$ of compounds 1 and 3 with a variety of putative anionic guests (added as tetrabutylammonium salts) at $298 \mathrm{~K}$ in DCM- $d_{2}{ }^{a}$ In all cases a $1: 1$ receptor : anion stoichiometry was observed. Data fitted using EQNMR. $^{20}$

Compounds

\begin{tabular}{lcc}
\hline Anion & $\mathbf{1}$ & $\mathbf{3}$ \\
$\mathrm{Cl}^{-}$ & 238 & 257 \\
$\mathrm{Br}^{-}$ & 67 & 92 \\
$\mathrm{C}_{6} \mathrm{H}_{5} \mathrm{CO}_{2}^{-}$ & 709 & 251 \\
$\mathrm{HSO}_{4}^{-}$ & 14 & 16 \\
$\mathrm{H}_{2} \mathrm{PO}_{4}^{-}$ & 128 & 68 \\
${ }^{a}$ Error estimated to be no more than $\pm 15 \%$ &
\end{tabular}

Table 2 Stability constants $\left(\mathrm{M}^{-1}\right)$ of compounds $\mathbf{1 - 4}$ with a variety of putative anionic guests (added as tetrabutylammonium salts) at $298 \mathrm{~K}$ in DMSO$d_{6} / 0.5 \%$ water. $^{a}$ In all cases a $1: 1$ receptor : anion stoichiometry was observed.

Compounds

\begin{tabular}{lcccc}
\hline Anion & $\mathbf{1}$ & $\mathbf{2}$ & $\mathbf{3}$ & $\mathbf{4}$ \\
$\mathrm{Cl}^{-}$ & $<10$ & $<10$ & $<10$ & $<10$ \\
$\mathrm{CH}_{3} \mathrm{CO}_{2}^{-}$ & 85 & 28 & 13 & 38 \\
$\mathrm{C}_{6} \mathrm{H}_{5} \mathrm{CO}_{2}^{-}$ & 44 & 33 & $<10$ & 21 \\
$\mathrm{H}_{2} \mathrm{PO}_{4}^{-}$ & 64 & 63 & 19 & 122
\end{tabular}

${ }^{a}$ Error estimated to be no more than $\pm 15 \%$

Table 3 Stability constants $\left(\mathrm{M}^{-1}\right)$ of compounds 5 and 6 with a variety of putative anionic guests (added as tetrabutylammonium salts) at $298 \mathrm{~K}$ in DMSO- $d_{6} / 0.5 \%$ water. ${ }^{a}$ In all cases a $1: 1$ receptor : anion stoichiometry was observed.

Compounds

\begin{tabular}{lll}
\hline Anion & 5 & 6
\end{tabular}




$\begin{array}{lcc}\mathrm{Cl}^{-} & 10 & 27 \\ \mathrm{Br}^{-} & - & <10 \\ \mathrm{CH}_{3} \mathrm{CO}_{2}^{-} & 277 & 2540 \\ \mathrm{C}_{6} \mathrm{H}_{5} \mathrm{CO}_{2}^{-} & 107 & 586 \\ \mathrm{H}_{2} \mathrm{PO}_{4}^{-} & 370 & 1170 \\ { }^{-} \text {Error estimated to be no more than } \pm 15 \% & \end{array}$

${ }^{a}$ Error estimated to be no more than $\pm 15 \%$ 